\title{
Mosaic Physics and the Search for a Pious Natural Philosophy in the Late Renaissance
}

\section{Citation}

Blair, Ann. 2000. Mosaic physics and the search for a pious natural philosophy in the late Renaissance. Isis 91(1): 32-58.

\section{Published Version}

http://dx.doi.org/10.1086/384625

\section{Permanent link}

http://nrs.harvard.edu/urn-3:HUL.InstRepos:3373450

\section{Terms of Use}

This article was downloaded from Harvard University's DASH repository, and is made available under the terms and conditions applicable to Other Posted Material, as set forth at http:// nrs.harvard.edu/urn-3:HUL.InstRepos:dash.current.terms-of-use\#LAA

\section{Share Your Story}

The Harvard community has made this article openly available.

Please share how this access benefits you. Submit a story.

Accessibility 


\title{
Mosaic Physics and the Search for a Pious Natural Philosophy in the Late Renaissance
}

\author{
By Ann Blair*
}

\begin{abstract}
In the tense religious climate of the late Renaissance (ca. 1550-1650), traditional charges of impiety directed against Aristotle carried new weight. Many turned to alternative philosophical authorities in the search for a truly pious philosophy. Another, "most pious" solution was to ground natural philosophy on a literal reading of the Bible, especially Genesis. I examine this kind of physics, often called Mosaic, or sacred, or Christian, through the example of Johann Amos Comenius and those whom he praises as predecessors in his attempt to reform physics according to the "divine light" of Scripture. In analyzing the works of these authors, I conclude that what they shared most effectively was an agenda rather than a practice. They defended the single, universal truth of a "Christian philosophy" grounded in biblical literalism against the impious excesses of philosophical naturalism, on the one hand, and against the antiphilosophical attacks of extreme theologians, on the other hand. This peculiar strand of natural philosophy, neither traditional nor "modern," needs to be included in attempts to map the complex dynamics of contemporary debates and self-presentations.
\end{abstract}

\section{THE IDEAL OF A PIOUS PHILOSOPHY}

The religious objections raised against Aristotelian philosophy at its first entry into the European universities are well known. The condemnations of 1277 were quite ineffective in their attempt to keep Aristotelianism out of university curricula, however. Less well known is the role that religious objections played once again, in the sixteenth and seventeenth centuries, in undermining Aristotelianism, this time with considerably more suc-

\footnotetext{
* Department of History, Harvard University, Cambridge, Massachusetts 02138.

This research was partially funded by a grant from the National Endowment for the Humanities. I am grateful to the participants at a conference at the Internationales Forschungszentrum in Vienna in 1996, where this work was first presented, and at the HSS session in San Diego; and to Mordechai Feingold, Anthony Grafton, James Hankins, Howard Louthan, and the anonymous referees for Isis for helpful comments on earlier written versions.
} 
cess. ${ }^{1}$ Most of the new philosophies proposed in this period, from Marsilio Ficino's revival of Platonism in the fifteenth century to Robert Boyle's experimental natural philosophy in the mid seventeenth, were billed as more pious or Christian than the dominant Aristotelian philosophy, and their authors used this argument to help justify the move to replace Aristotelianism. Even René Descartes, in devising his new philosophy, felt that he was fulfilling a mission assigned him by Cardinal Bérulle, one of the leading figures of the French Counter-Reformation. In the renewed quest for a pious natural philosophy in the late Renaissance, many championed other ancient philosophies, like Epicureanism (Pierre Gassendi) or Stoicism (Justus Lipsius) or varieties of neo-Platonism (Marsilio Ficino, Bernardino Telesio, Francesco Patrizi). But resorting to other pagan philosophers posed in a new way the same problem as had Aristotelianism: these authorities too had to be Christianized. ${ }^{2}$ Hence the appeal of another, potentially more radical solution, which I examine here: using the Bible as a source of natural philosophical knowledge to supplement or in some cases to replace Aristotle. In this essay I focus on a particular subgroup of the many who searched for a pious or Christian philosophy in the late Renaissance: those who proposed a solution based on a literal reading of the Bible and whose particular emphasis on Genesis earned them the appellation of "sacred" or "Mosaic" philosophers.

No doubt almost all philosophers in early modern Europe wanted their philosophy to concord with religion and could be called "pious" in this weak sense. The majority of philosophers felt that they were best serving the interests of their religion by remaining faithful to Aristotelianism, for which the work of Christianizing had already been performed, notably by a variety of scholastic philosophies. Thus for a professor at the University of Paris in the first half of the seventeenth century - in a complete reversal of the situation in 1277 - to criticize Aristotle (as, for example, Gassendi and the chemical philosophers did) was to be impious. To support Aristotle as the philosophical pillar of the Thomist synthesis, on the other hand, was to choose a philosophy that was guaranteed to accord with religion. The Church also called on Aristotelian philosophers to make their science better serve religion. In particular, the Fifth Lateran Council (1512-1517) mandated that philosophers develop demonstrations of the religious doctrine of the immortality of the soul. Only a very few philosophers, like Pietro Pomponazzi at Padua, responded by

\footnotetext{
${ }^{1}$ For the most recent account of thirteenth-century objections to Aristotelian philosophy see J. M. M. H. Thijssen, "What Really Happened on 7 March 1277? Bishop Tempier's Condemnation and Its Institutional Context," in Texts and Contexts in Ancient and Medieval Science: Studies on the Occasion of John E. Murdoch's Seventieth Birthday, ed. Edith Sylla and Michael McVaugh (Leiden: Brill, 1997), pp. 84-105. A recent account of Renaissance philosophy brings the later religious anti-Aristotelianism to the fore; see Stephen Menn, "The Intellectual Setting," in The Cambridge History of Seventeenth-Century Philosophy, ed. Daniel Garber and Michael Ayers (Cambridge: Cambridge Univ. Press, 1998), pp. 33-86.

${ }^{2}$ On Robert Boyle, whose Christian Virtuoso (1690) offers an interesting variation on the theme of pious philosophy, see Jan W. Wojcik, Robert Boyle and the Limits of Reason (Cambridge: Cambridge Univ. Press, 1997); and Reijer Hooykaas, Robert Boyle: A Study in Science and Christian Belief (Lanham, Md.: Univ. Press America, 1997). On Descartes's meeting with Bérulle see Adrien Baillet, La vie de Monsieur Descartes (Paris, 1691; rpt., New York: Garland, 1987), Vol. 2, ch. 14, pp. 165-166. For a comparison of Cartesian and Thomist strategies for making science pious see Rivka Feldhay and Michael Heyd, "The Discourse of Pious Science," Science in Context, 1989, 3:109-142. On attempts to Christianize other pagan philosophers see Margaret Osler, "Baptizing Epicurean Atomism: Pierre Gassendi on the Immortality of the Soul," in Religion, Science, and Worldview: Essays in Honor of Richard S. Westfall, ed. Osler and Paul Lawrence Farber (Cambridge: Cambridge Univ. Press, 1985), pp. 163-184; and Osler, "Fortune, Fate, and Divination: Gassendi's Voluntarist Theology and the Baptism of Epicurus," in Atoms, Pneuma, and Tranquillity: Epicurean and Stoic Themes in European Thought, ed. Osler (Cambridge: Cambridge Univ. Press, 1991), pp. 155-174. On Patrizi see Luc Deitz, "Space, Light, and Soul in Francesco Patrizi's Nova de universis philosophia," in Natural Particulars: Nature and the Disciplines in Renaissance Europe, ed. Anthony Grafton and Nancy Siraisi (Cambridge, Mass.: MIT Press, forthcoming), pp. 139-169.
} 
defending the independence of philosophy from religion to the extent of arguing that philosophy could reach truths different from (although possibly still subordinate to) those of religion. ${ }^{3}$ Even Pomponazzi soon published a retraction of the arguments of his De immortalitate animi (1513) that included philosophical demonstrations of the immortality of the soul, in accordance with the conciliar decree. Aristotelians thus readily justified their philosophy as one that accorded well with Christianity.

The specific expressions "pious philosophy" and "Christian philosophy," however, became current in the Renaissance to designate philosophies opposed to Aristotelianism. The phrase "Christian philosophy" has been traced to just one earlier occurrence, in St. Augustine (where it serves as a synonym for "Christian religion"), and has recurred most recently in modern debates over the possibility of a "Christian philosophy" and whether Thomism fits the bill. ${ }^{4}$ Although Petrarch initiated the humanist critiques of scholastic Aristotelianism on moral and religious grounds, Ficino was probably the first to call his philosophy, developed from a reading of Plato colored by neo-Platonism, a "pia philosophia." After him Platonists commonly invoked "piety," and in particular agreement with the Mosaic account of Genesis, as grounds for preferring Plato to Aristotle. In the later sixteenth and seventeenth centuries, with the multiplication of philosophical alternatives to Aristotle, pious philosophy was no longer exclusively associated with Platonism but could appeal to a number of different anti-Aristotelian foundations. Stephen Menn has gone so far as to conclude "that all new [i.e., anti-Aristotelian] philosophers were necessarily Mosaic philosophers," in that they argued for the superiority of their natural philosophy on the basis of its compatibility with the biblical, specifically the Mosaic, account of nature: "A Renaissance thinker could pass easily and continuously from arguing defensively that his chosen philosophy was compatible with scripture, to arguing offensively that his philosophy was more compatible with scripture than others were, to proving that his chosen philosophy was implicitly contained in scripture, to constructing a whole new philosophy out of hints in the sacred books." The temptation to claim biblical support for

\footnotetext{
${ }^{3}$ On the usefulness of Aristotle for philosophers at the university see Ann Blair, "The Teaching of Natural Philosophy in Early Seventeenth-Century Paris: The Case of Jean Cécile Frey," History of Universities, 1993, 12:95-158, on pp. 117-119. For an introduction to the Fifth Lateran Council and for further references see Christia Mercer, "The Vitality and Importance of Early Modern Aristotelianism," in The Rise of Modern Philosophy: The Tension between the New and Traditional Philosophies from Machiavelli to Leibniz, ed. Tom Sorell (Oxford: Clarendon, 1993), pp. 33-67, on pp. 46-49. On the difficulties involved in interpreting Pomponazzi's position see Martin L. Pine, Pietro Pomponazzi: Radical Philosopher of the Renaissance (Padua: Editrice Antenore, 1986), pp. 3-39.

${ }^{4}$ On the modern debate, opened in 1928, see Alexandre Charles Renard, La querelle sur la possibilité de la philosophie chrétienne (Paris: Editions Ecole et Collège, 1941); and Maurice Nédoncelle, Existe-t-il une philosophie chrétienne? (Paris: Librairie Arthème Fayard, 1959). For occurrences of the term in St. Augustine, in a few early modern authors (including Erasmus, Suarez, and Javelli), and in dozens of authors in the nineteenth and twentieth centuries see the references accumulated by Etienne Gilson, a major player in the modern debate, in his "Notes bibliographiques pour servir à l'histoire de la notion de philosophie chrétienne," in L'esprit de la philosophie médiévale, 2nd ed. (Paris: Vrin, 1944), pp. 413-440; see p. 413 on Augustine. Paul Oskar Kristeller comments that further references from Justin, Petrarch, and Calvin could be added; see Kristeller, "Thomism and the Italian Thought of the Renaissance," in Medieval Aspects of Renaissance Learning: Three Essays by Paul Oskar Kristeller, ed. and trans. Edward P. Mahoney (New York: Columbia Univ. Press, 1992), pp. 29-91, on p. $34 \mathrm{n} 7$.

${ }^{5}$ Petrarch's critique is described in Menn, "Intellectual Setting" (cit. n. 1), p. 41 ff.; and Paul Oskar Kristeller, "Petrarch," in Eight Philosophers of the Italian Renaissance (Stanford, Calif.: Stanford Univ. Press, 1964), p. 6 ff. On Ficino's use of the term see James Hankins, "Marsilio Ficino and the Tradition of Pious Philosophy," paper read at a conference entitled "Marsilio Ficino: His Sources, His Circle, His Legacy," sponsored by the Society for Renaissance Studies, National Gallery, London, 25-26 June 1999 (publication pending); I am grateful to the author for sharing this manuscript with me. See also Hankins, "Marsilio Ficino as a Critic of Scholasticism," Vivens Homo, 1994, 5:325-334.
} 
one's philosophy was so great that "there is at least a bit of 'Mosaic philosophy' in almost every thinker of the time," including Descartes. ${ }^{6}$

The Mosaic philosophers I will consider here took this tendency to its logical extreme and advocated a philosophy drawn primarily from biblical authority, although they too did not always practice what they preached and in the end also relied on Aristotelian categories. In their call to reject received (Aristotelian and human) authority, their strategy can sound quite modern at times. They appealed to a single, universal truth that transcended religious divides, and they pursued an irenic ideal at the height of the European wars of religion (ca. 1570-1630). In response to the traumatic splintering of Christianity and the growing dissatisfaction with the inadequacies of Aristotle and other ancient authorities, they harbored and fostered high hopes of resolving philosophical and religious diversity by grounding philosophy in the most indisputable authority - that of the Bible. But in their search for a pious philosophy, these authors were genuinely concerned to keep both philosophy (against those who would eliminate it from the studies of the godly, a move afoot among some strict Lutherans in the late sixteenth century) and piety (against those enamored with Aristotelian naturalism). They articulated most explicitly and cogently the concern central to the centuries-old and still ongoing efforts to devise a philosophy fundamentally compatible with piety and in so doing forged a path distinct from both the traditionalists and those who in the end prevailed as the "moderns."

\section{COMENIUS AS AN EXPONENT OF MOSAIC PHILOSOPHY}

Although modern historians of science have mostly neglected or hastily dismissed this strand of early modern philosophy, the first historians of philosophy active in the eighteenth century, like Johann Jakob Brucker, in describing philosophical developments since the Renaissance, reserved a category for "Mosaic and Christian philosophers" alongside other, more familiar categories including Aristotelians, Platonists, Epicureans, Stoics, Skeptics, Theosophs, and Syncretists. ${ }^{7}$ Brucker describes how some philosophers, in avoiding the Scylla of skepticism, foundered on the Charybdis of seeking in the Bible the foundations of natural and moral science. In his negative assessment of this strategy Brucker distinguishes between two different ways of misusing the Bible:

\footnotetext{
${ }^{6}$ Menn, "Intellectual Setting," pp. 58, 82. He cites Lipsius and Cudworth as examples and points to a passage in which Descartes offers to explain Genesis with his philosophy: René Descartes, Oeuvres, ed. Charles Adam and Paul Tannery (Paris: Vrin, 1996), Vol. 5, pp. 168-169. See also René Descartes to William Boswell[?], 1646[?], ibid., Vol. 4, p. 698; I owe this reference to an anonymous referee. The offer to explain Genesis is also mentioned as relevant in Daniel Georg Morhof, Polyhistor, literarius, philosophicus et practicus, 3rd ed. (Lübeck: Petrus Boeckmann, 1732), Vol. 2, Pt. 1, ch. 3, p. 159, which cites Descartes, Epistolae [partim ab auctore latino sermone conscriptae, partim ex gallico translatae] (Amsterdam: Blaviana, 1682), Vol. 2, ep. 24 [p. 108], as well as Vol. 2, ep. 53 [p. 206]; the latter reference corresponds to Descartes to Marin Mersenne, 28 Jan. 1641, in Descartes, Oeuvres, ed. Adam and Tannery, Vol. 3, pp. 295-296. Examples of the Platonist use of the argument from piety include Sebastian Fox Morzillo, De naturae philosophia seu de Platonis et Aristotelis consensione libri V (Louvain, 1554; rpt., Hildesheim: Olms, 1977); Georgius Acanthius, Platonicae philosophiae libri tres (Basel: Oporinus, 1554); and Francesco Verino, Antonio Montecatini, and Francesco Patrizi, as discussed in Hankins, "Marsilio Ficino and the Tradition of Pious Philosophy."

${ }^{7}$ See Johann Jakob Brucker, Historia critica philosophiae (Leipzig: Bernhard Christoph Breitkopf, 1743), Vol. 4 ("A tempore resuscitatarum in Occidente literarum"), Pt. 1, bk. 3, ch. 2, pp. 610-643, on Mosaic philosophers. Among modern historians of science Reijer Hooykaas, for example, mentions Mosaic philosophy only to dismiss it as a "temptation" that found no general acceptance; see Hooykaas, Religion and the Rise of Modern Science (Edinburgh/London: Scottish Academic Press, 1972), p. 116. In Humanisme, science et réforme: Pierre de La Ramée (1515-72) (Leiden: Brill, 1958), pp. 108-112, Hooykaas alludes to it again, subsuming it under the search for a "prisca theologia"; on this strand of thought see note 10, below.
} 
Some, following the letter of Scripture, used what the sacred writers touched on [in passing] rather than recounted [at length] concerning cosmogony and natural things in order to build a new sacred physics. . . . Hence they are called Mosaic and Christian philosophers. Others, damping down the light of the intellect, called for some other more divine and more perfect light stemming from heavenly revelation to be the foundation of philosophy, neglecting the letter of Scripture and [relying on] the intermediary of the machine of allegory.... That kind of philosophy let itself be called and called itself theosophical.

Brucker devotes a chapter to each, separating those who advocated a literalist use of the Bible (among whom he includes Francisco Vallès, Otto Casmann, Johann Heinrich Alsted, Conrad Aslacus, Lambert Daneau, and Johann Amos Comenius) from those like Paracelsus, Jakob Boehme, Robert Fludd, and their followers, who also proclaimed their philosophies to be uniquely Christian because grounded in divine revelation but who read the Bible through layers of allegory and personal inspiration foreign to the properly "Mosaic and Christian philosophers." 8

To be sure, one could conjoin these two kinds of philosophers under the same category, as Daniel Georg Morhof did in his chapter on "Mosaic physics" in the Polyhistor (in a section published posthumously in 1708 from Morhof's notes). Following his "invective" against the "inept piety, or rather superstition," of those who believe that the principles of all sciences are hidden in sacred Scripture, Morhof includes in this chapter those who tried to reconcile the account of Moses with Platonic, Cartesian, and Aristotelian principles, among them Henry More the Platonist, Johannes Amerpoel the Cartesian, Robert Fludd, who "was mixed up," and Daneau, Aslacus, and Alsted, whom he considers excessively beholden to Aristotelianism. But Morhof also mentions alchemical authors like Jean d'Espagnet, "cabbalists" like Francesco Giorgi, "enthusiasts" like Jakob Boehme and Quirinus Kühlmann, and Rosicrucians like Aegidius Guthmann and John Heydon. Morhof gives the most consideration to Comenius and his follower Johan Bayer, as the only ones to have built a new system of physics methodically on Mosaic foundations. ${ }^{9}$ Further research into other early histories of philosophy could better illuminate the shifting boundaries of the flexible category of "Mosaic philosophy." But modern commentators have

\footnotetext{
${ }^{8}$ Brucker, Historia critica, Vol. 4, pp. 610-611: "Quidam literam scripturae sequentes, quae de cosmogonia rebusque naturalibus sacri scriptores tetigerunt magis, quam enarrarunt, ad construendam novam physicam sacram adhibuerunt. ... Mosaici et Christiani philosophi inde dicti sunt. Alii depressa intellectus luce connata, lumen aliud et divinum longe maius et perfectius ex coelesti revelatione fundamentum esse debere philosophiae clamarunt, adeoque neglecta scripturae litera, mediante allegoriae machina. ... Quod genus philosophorum ... theosophicum se et dici passum est, et ipsum appellavit." See also ibid., pp. 612 (Vallès), 614-617 (Casmann, Alsted, Aslacus, Daneau), 628 ff. (Comenius); and ibid., Pt. 1, bk. 3, ch. 3, pp. 644-750, on the theosophs. Much of the same material can be found in Johann Jakob Brucker, Kurze Fragen aus der philosophischen Historie (Ulm: Daniel Bartholomaeus, 1735), pp. 993-1062 ("Mosaici et Christiani"), 1063-1254 (theosophs).

${ }^{9}$ See Morhof, Polyhistor (cit. n. 6), Vol. 2, Pt. 1, ch. 3: "De Physica Mosaica, ejusque interpretibus," pp. 157167, esp. p. 160: "Qui dogmatica methodo complexus fuerit principia Mosaica, neminem novi, quam Comenium, et, qui ejus principia secutus est, Johan. Baierum. Rob. enim Fluddius, in Philosophia Mosaica sua, confusus est, et coelum terrae miscet, omnia pervagando. Lamb. Danaeus, Conr. Aslacus Joh. Henr. Alstedius ..., , ac alii qui Physicam Christianam scripserunt, nulla certa principia sequuntur, sed vel Interpretes sunt priorum Capitum Geneseos, vel Physicam Aristotelicam et vulgarem ad Mosaica illa reducunt." This section of Morhof's Polyhistor was compiled by Johannes Möller. The specific works Morhof mentions include Henry More, In defensione suae cabalae philosophicae, which probably corresponds to his Conjectura Cabbalistica (1653); Johannes Amerpoel, Cartesius Mosaizans (1669); Jean d'Espagnet, Enchiridion physicae restitutae (1647); Francesco Giorgi, De harmonia mundi (1545); Aegidius Guthmann, Offenbahrung göttlicher Majestät (1619); and John Heydon, The Harmony of the World (1662).
} 
tended to follow Brucker's distinction, separating (as I will too) the "genuine" Mosaic philosophers from those who made little pretense at a literal reading of the Bible. ${ }^{10}$

When one considers the categories used by the authors themselves involved in the development of Mosaic or rival philosophies some fifty to one hundred years before Brucker and Morhof, Brucker's narrower definition of Mosaic philosophers as biblical literalists indeed seems the dominant one. Thus one contemporary, in surveying the different kinds of natural philosophy of his day, named as "Mosaic" natural philosophers Daneau, Casmann, and Aslacus. Similarly, Johann Heinrich Alsted offered from within the camp of Christian philosophers a "biblical encyclopedia" of sacred philosophy, law, and medicine drawn from the Old and New Testaments. Alsted lists as his "most Christian" predecessors in various fields authors included among Brucker's literalists: in particular, for sacred physics, Vallès, Daneau, and Aslacus, to whom he adds Levinus Lemnius. Casmann is featured for his sacred ethics and economics; Conrad Heresbach for a compendium of law; and one Grossius for a compendium of medicine derived from Scripture. ${ }^{11}$ For Alsted, as for Brucker, Mosaic philosophy embraced a full range of disciplines, from natural philosophy (or physics) to ethics, law, and politics.

Probably the most articulate and most widely read of the "Mosaic" or "Christian" philosophers of the late Renaissance was Johann Amos Comenius (1592-1670). (See Figure 1.) Both Brucker and Morhof single out Comenius as surpassing others in his industry in developing and promoting this genre of philosophy. ${ }^{12}$ In his quest for support for his exiled

\footnotetext{
${ }^{10}$ Other early histories of philosophy include Johann Franz Buddeus, Introductio ad historiam philosophiae ebraeorum (Halle: Orphanotrophii Glaucha-Halensis, 1702); Nicolaus Hieronymus Gundling, Historia philosophiae moralis (1706); Gottlieb Stolle, Anleitung zur Historie der Gelahrheit (Jena: Meyer, 1724); and Johann Georg Walch, Philosophisches Lexicon (1726), cited in Jaromír Červenka, Die Naturphilosophie des Johann Amos Comenius (Prague: Academia, 1970), p. 105. Stolle seems to follow Morhof's broad construction of the category in Anleitung zur Historie der Gelahrheit, Pt. 2, ch. 4, sect. 29, pp. 541-545. Budde, who served as a source for his pupil Brucker and his son-in-law Walch, emphasized Comenius as the outstanding representative of Mosaic philosophy; see Buddeus, Introductio ad historiam philosophiae ebraeorum, par. 36, pp. 245-264, esp. p. 255. See also Hans Ahrbeck, "Einige Bemerkungen über 'Mosaische Philosophen' des 17. Jahrhunderts," Wissenschaftliche Zeitschrift der Martin-Luther-Universität Halle-Wittenberg, 1958, 7(5):1047-1050, on p. $1048 \mathrm{n} 7$. The category does not appear in Giovanni Santinello, ed., Models of the History of Philosophy (Dordrecht/Boston: Kluwer, 1993). The appellation "genuine" comes from Červenka, Naturphilosophie des Comenius, pp. 112-113, who also calls the group I will study "traditionalists"; see also Ahrbeck, "Bemerkungen über "Mosaische Philosophen," p. 1048. Another reason for choosing to narrow rather than broaden the scope of this study is that there already exists an abundant secondary literature on Paracelsus, Fludd, Boehme, and their followers; see, most recently, Wilhelm Schmidt-Biggemann, Philosophia Perennis: Historische Umrisse abendländischer Spiritualität in Antike, Mittelalter und Früher Neuzeit (Frankfurt: Suhrkamp, 1998).

${ }^{11}$ Gerhardus de Neufville, Physiologia seu physica generalis (Bremen, 1645), bk. 6, pp. 346-349, cited in Lynn Thorndike, A History of Magic and Experimental Science (New York: Columbia Univ. Press, 1958), Vol. 7, pp. 414-415. Johann Heinrich Alsted, Triumphus bibliorum sacrorum seu encyclopaedia biblica exhibens triumphum philosophiae, iurisprudentiae et medicinae sacrae, itemque sacrosanctae theologiae, quatenus illarum fundamenta ex scriptura Veteris et Novi Testamentis colliguntur (Frankfurt: Bartholomaeus Schmit, 1625), sigs. $3 \mathrm{v}-4 \mathrm{r}$ : "Intellexerunt hoc [that the holy scriptures contain a sublime erudition in philosophy, medicine, and law] superiori aevo viri Christianissimi, Franciscus Valesius Hispanus, Levinus Lemnius Belga, Lambertus Danaeus Gallus, Cunradus Heresbachius Germanus. ... Cunradus Heresbachius publicavit epitomen iurisprudentiae Christianae, in qua leges Moysis elegantissimo ordine digessit. Tantorum virorum vestigia secuti sunt nostra aetate Otho Casmannus in ethica et oeconomica theosophica; Iohannes Althusius in civili conversatione; Grossius in compendio medicinae ex S. literis deprompto; et Conradus Aslacus Danus, qui scripsit Physicam et ethicam mosaicam." Alsted is no doubt referring to Otto Casmann, Biographia, sive de vita hominis naturali . . Ethica theosophica ... Oeconomica theosophica (Frankfurt: Palthenius, 1602); Conrad Heresbach, Christianae iurisprudentiae epitome, cited in Allgemeine Deutsche Biographie, 2nd ed. (Berlin: Duncker \& Humblot, 19671971), Vol. 12, p. 105; Iohannes Althusius, Civilis conversationis libri II (Hanau, 1601); and possibly to Johann Georg Grossius, Compendium quatuor facultatum (including medicine) (Basel, 1620).

${ }^{12}$ Brucker, Historia critica (cit. n. 7), Vol. 4, p. 628: "Enarrandi iam paulo plenius Comenii et Bayeri conatus sunt, eo quod prae aliis in hoc philosophiae genere exornando commendandoque industriam posuerunt suam."
} 


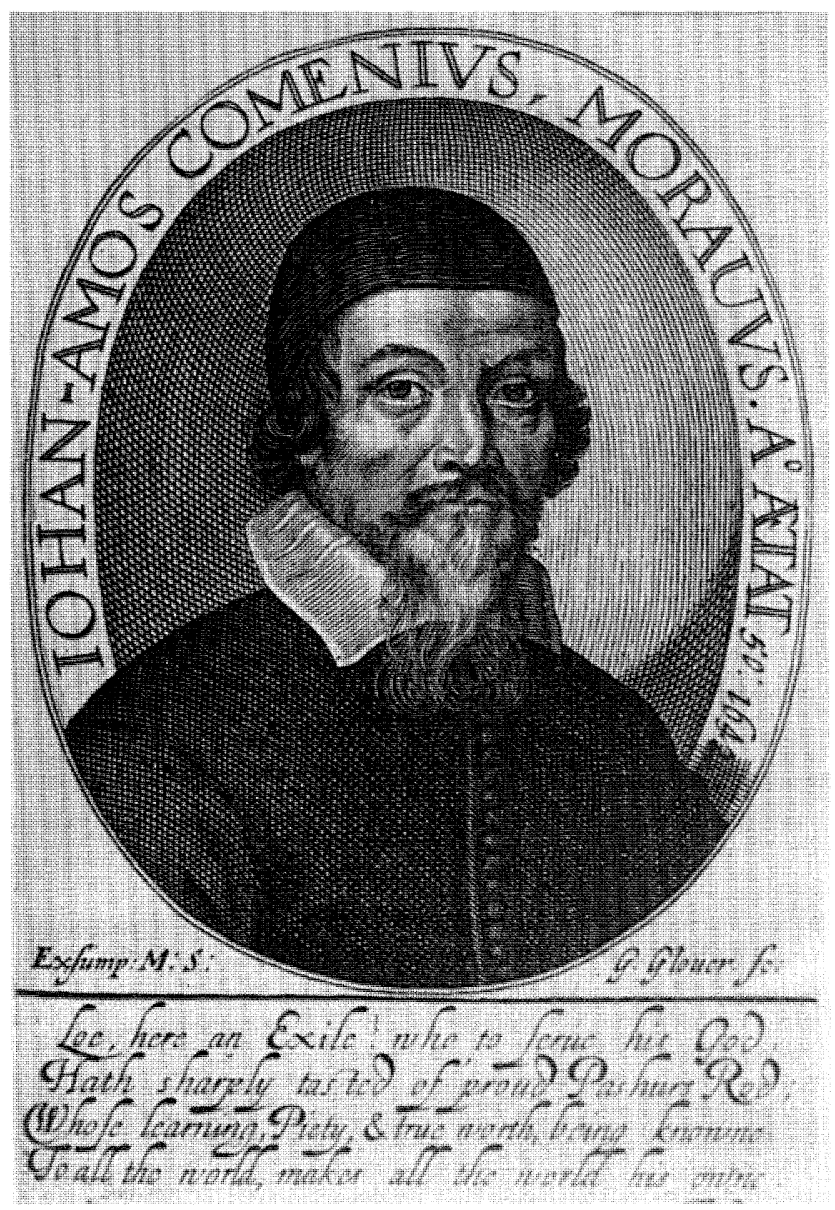

Figure 1. Johann Amos Comenius. Engraving by George Glover (1642). By permission of the National Portrait Gallery, London.

flock of Bohemian Brethren and his own pansophic projects, Comenius traveled and published widely, using the vernacular as well as Latin to reach audiences beyond the scholarly elite. Comenius achieved an international reputation and was particularly warmly received in England by Samuel Hartlib and his circle, who might have implemented some of Comenius's plans if the political turmoil of the 1640 s had not rapidly put an end to the patronage they had promised. The negative assessment of his work in Pierre Bayle's Dictionnaire historique et critique of 1697, which antedates the critiques of Mosaic philosophy more generally by Brucker and Morhof, gives a clear indication of the limited chronological span of his appeal, which was in any case never universal. But at midcentury Comenius was well known as a uniquely explicit visionary who saw in pious philosophy the key to a reformation of knowledge and to the realization of pansophy-wisdom for everyone

For Morhof's assessment see note 9, above. Johan Bayer, from Hungary, was the author of Ostium seu atrium naturae (Cassovia/Kaschau [Hungary], 1662). See Brucker, Historia critica, Vol. 4, p. 632 ff.; and Ahrbeck, "Bemerkungen über 'Mosaische Philosophen"” (cit. n. 10), p. 1048. 
everywhere, in agreement safe from confessional divisions. ${ }^{13}$ Comenius's treatment of natural philosophy and the list of authors he praises as having preceded him in the elaboration of a "Christian physics" provide an excellent point of departure for analyzing the assumptions and methods of this strand of pious philosophy.

Comenius's Physicae ad lumen divinum reformatae synopsis (1633) appeared in the same year as his famous Janua linguarum reserata. Although little studied, Comenius's treatment of natural philosophy appeared in at least four additional Latin editions and an English translation, Naturall Philosophie Reformed by Divine Light; or, A Synopsis of Physicks (London, 1651). ${ }^{14}$ (See Figure 2.) Composed during his period of teaching at the gymnasium of Leszno (Poland), the work presumably represents part of Comenius's projected educational reform. Comenius announces his debt to Alsted's "Triumphus biblicus," in which his "honoured Master" has shown that "for whatsoever matter is to be handled, the Scripture affords always, either a rule, or some sayings or examples." In particular, then, for his reformation of physics Comenius proposes "a draught of the lineaments of some new (and as I hope truly Christian) philosophie," grounded on three basic principles:

I. That the onely true, genuine and plain way of Philosophie is to fetch all things from sense, reason and Scripture.

II. That the Peripatetick philosophie is not onely defective in many parts, and many ways intricate, full of turnings and windings, and partly also erroneous, so that it is not onely unprofitable for Christians but also (without correction and perfection) hurtfull.

III. That Philosophie may be reformed and perfected, by an harmonical reduction of all things

${ }^{13}$ On Comenius in England see Robert Fitzgibbon Young, Comenius in England (London: Oxford Univ. Press, 1932); Hugh Trevor-Roper, "Three Foreigners: The Philosophers of the Puritan Revolution," in Religion, the Reformation, and Social Change, 2nd ed. (London: Macmillan, 1972), pp. 237-293; and George H. Turnbull, Samuel Hartlib, with Special Regard to His Relations with J. A. Comenius, Inaugural-dissertation zur Erlangung der Doktorwürde, Bonn (London: Spottiswoode, Ballantyne, 1919). On the patronage Comenius received and was promised see Mark Greengrass, "The Financing of a Seventeenth-Century Intellectual: Contributions for Comenius, 1637-1641," Acta Comeniana, 1995, 11:71-87. For Bayle's negative assessment see Pierre Bayle, Dictionnaire historique et critique (Amsterdam: Brunel, et al., 1730), Vol. 2, pp. 202-205. The literature on Comenius is vast; I have found Hans Aarsleff's entry in the Dictionary of Scientific Biography (Vol. 3, pp. 359363) especially helpful. The best biography is Milada Blekastad, Comenius: Versuch eines Umrisses von Leben, Werk und Schicksal des Jan Amos Komensky (Oslo: Universitetsforlaget; Prague: Academia, 1969). Among the most recent literature see Pauline van Vliet and Arie Johan Vanderjagt, eds., Johannes Amos Comenius (15921670): Exponent of European Culture? (Amsterdam: North-Holland, 1994); and Klaus Schaller, Comenius 1992: Gesammelte Beiträge zum Jubiläumsjahr (Sankt Augustin, Germany: Academia, 1992).

${ }^{14} \mathrm{~J}$. A. Comenius, Physicae ad lumen divinum reformatae synopsis, philodidacticorum et theodidactorum [sic] censurae exposita (Leipzig: Gotofredus Grossius, 1633). Re-editions appeared in Amsterdam in 1643 and 1645 and in Paris in 1647; it was also issued, under a revised title that emphasized that the reformation of physics remained to be completed, as Physicae ad lumen divinum reformandae synopsis in Amsterdam in 1663 . The British Library also owns a Latin edition published in Giessen in 1896 by Joseph Reber, which includes a careful introduction and commentary, according to Ahrbeck, "Bemerkungen über 'Mosaische Philosophen'" (cit. n. 10), nn. 5, 20. In addition to reporting a first edition of Amsterdam, 1632 (otherwise unattested), Brucker notes that Ioachim Lange published theses from the book, once it could no longer be found for sale, as Theses physicae comenianae ad lumen divinum reformatae (Berlin, 1702); see Brucker, Kurze Fragen (cit. n. 8), p. 1035. The English translation, Naturall Philosophie Reformed by Divine Light; or, A Synopsis of Physicks (London: Robert and William Leybourn, for Thomas Pierrepont, 1651), seems faithful to the Latin original, although it lacks the prefatory poem by Andreas Wengerscius, rector of the school at Leszno. All further references to Comenius in this essay will be to the English edition of this work. For a monograph on Comenius's natural philosophy, which relies primarily but not exclusively on this work, see Červenka, Naturphilosophie des Comenius (cit. n. 10). A recent article on the Physicae synopsis offers a valuable analysis, in particular of its biblical citations; see JeanRobert Armogathe, "La Physica sacra de Comenius comme physique chrétienne," Nouvelles de la République des Lettres, 1996, 1:7-16. Armogathe also signals the existence of a seventeenth-century Danish translation of the work, without giving a full bibliographical citation. 


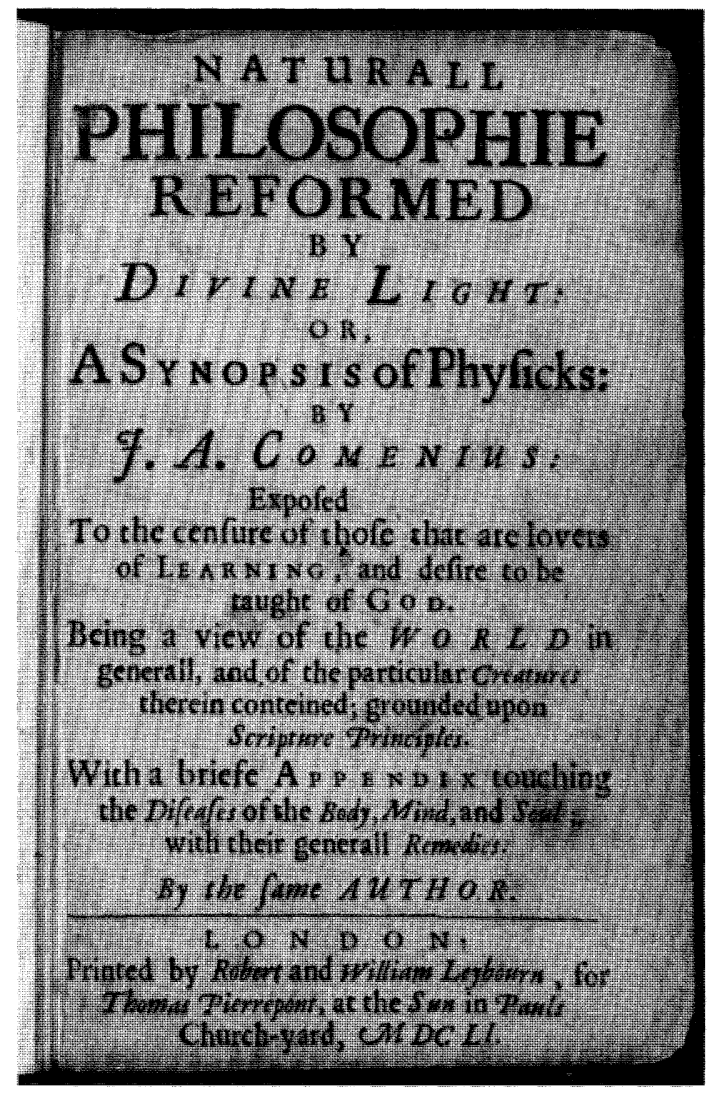

Figure 2. Title page of Johann Amos Comenius, Naturall Philosophie Reformed by Divine Light (London, 1651). By kind permission of the University of Michigan Library.

that are and are made, to sense, reason and Scripture, with so much evidence and certainty ... that any mortal man seeing may see, and feeling may feel, the truth scattered every where. ${ }^{15}$

In calling for the correction of received Aristotelian philosophy Comenius envisions a physics based on the conjoined evidence of "sense, reason and Scripture," as if their agreement would be unproblematic.

Comenius calls for a balance between extremes of rationalism and biblicism. To trust sense or reason alone would lead to predictable errors and abstractions. But, similarly, the Bible alone is not a sufficient guide:

They that heed the Scripture onely and hearken neither to sense nor reason are either carried away beyond the world (by the sublimity of their conceptions) or else involve things they understand not with the Colliers [unquestioning, blind] faith; or following the letter, propound unto themselves things, though never so absurd and superstitious, to be believed; as the papists

\footnotetext{
${ }^{15}$ Comenius, Naturall Philosophie Reformed by Divine Light, sigs. 5r-v, A3v, 6v-7r. See Blekastad, Comenius (cit. n. 13), pp. 176 (on the composition of the work), 176-184 (on its content). By "Triumphus biblicus" Comenius is no doubt referring to Alsted's Triumphus bibliorum sacrorum seu encyclopaedia biblica (cit. $n$.
} 11). 
do in that most absurd transubstantiation of theirs, etc. So then the principles of knowing must be conjoyned, that divine revelation may afford us belief; Reason, Understanding; Sense, certainty. And they must be used in this order (in naturall things I say) as that we begin with sense, and end in Revelation (as it were the setting to the seal of God:) for by this order every subsequent degree will receive from the antecedent, both Evidence and also Certainty and Emendation.

In Comenius's program reason is ultimately subordinate, however. Just as raw sense experience is corrected by reason (for example, in the case of optical illusions), so too reason is subject to correction by faith. This correction is "not violent . . . but gentle, so that that very thing which is corrected, acknowledgeth, and admits it of its own accord, and with joy." Reason and philosophy are therefore not to be rejected, but their limitations should be acknowledged and then overcome by turning to the final authority of divine light. Thus Comenius summarizes, in descending order of their corrective powers, the three elements of his "truer way": "by the Guidance of God, the Light of Reason and the Testimonie of Sense [Deo duce, ratione luce, sensu teste]."16

In his criticism of received opinion and his rejection of ancient and other philosophical authorities Comenius may sound quite modern. Nonetheless, he explicitly distinguishes himself from Francis Bacon, whom he first praises for opening a new way freed from Aristotelian authority, but whom he finds disappointing in the end: "Yet it grieved me again, that I saw most noble Verulam present us indeed with a true key of Nature, but not open the secrets of Nature, onely shewing us by a few examples, how they were to be opened; and leave the rest to depend on observations and inductions continued for several ages." Impatient with the slow progress of the methods that Bacon had introduced precisely to ensure the truth of his conclusions (e.g., the injunction "to abstain from axioms till full inductions could be made"), Comenius proposes to progress faster by relying on biblical inspiration:

Not that I would crosse the design of great Verulam (who thought it the best way to abstein from Axiomes and method, till full inductions could be made, of all and every thing throughout all nature:) but to make an experiment in the mean time, whether more light might be let into our minds by this means to observe the secrets of nature the more easily, that so praise might be perfected to God out of the very mouth of infants, and confusion prepared for the gainsaying enemies; as David having comprised the summe of Physicks in a short hymne for the use of the unlearned speaks (Psalm 8). I have entituled it a Synopsis of Physicks reformed by divine light.

In Comenius's view, drawing natural philosophical statements out of the Bible promises more rapid progress toward the twin goals of the discipline-certain causal knowledge and the praise of God-and a quicker refutation of Peripatetic enemies. Given his millenarian convictions, Comenius was particularly concerned with attaining results as quickly as possible. ${ }^{17}$

But in grounding this "Christian philosophy" on biblical authority Comenius clearly parts company with Bacon. For Comenius, "Philosophy is lame without divine Revela-

\footnotetext{
${ }^{16}$ Comenius, Naturall Philosophie Reformed by Divine Light, sigs. [8]v, a1v, A4r; for the Latin original see Comenius, Physicae ad lumen divinum reformatae synopsis (1633) (cit. n. 14), sig. c3r.

${ }^{17}$ Comenius, Naturall Philosophie Reformed by Divine Light, sigs. 6v, A3r-v. On Comenius's millenarianism see Wilhelm Schmidt-Biggemann, "Enzyklopädie, Eschatologie und Ökumene: Die theologische Bedeutung von enzyklopädischen Wissen bei Comenius," Frühneuzeit-Info, 1992, 3:19-28.
} 
tion." Bacon, by contrast, warns against "mixtures of theology with philosophy" and rejects precisely this kind of biblical philosophy when he complains:

Yet in this vanity some of the moderns have with extreme levity indulged so far as to attempt to found a system of natural philosophy on the first chapter of Genesis, on the book of Job, and other parts of the sacred writings, seeking for the dead among the living; which also makes the inhibition and repression of it the more important, because from this unwholesome mixture of things human and divine there arises not only a fantastic philosophy but also a heretical religion. Very meet it is therefore that we be sober-minded, and give to faith that only which is faith's.

Although Bacon does not specify whom he meant to target in this passage, he clearly identifies the project of Mosaic philosophy as a contemporary phenomenon and as a real threat to the proper demarcation of philosophy and religion. ${ }^{18}$

\title{
COMENIUS'S “MOST CHRISTIAN PHILOSOPHERS”
}

Comenius provides us with names where Bacon did not; he reserves unadulterated praise for an interesting list of predecessors in his project of a "Christian philosophy":

\begin{abstract}
Those most Christian Philosophers are therefore deservedly to be praised, who have endeavored to render unto God the Parent of things that praise that is due unto him: Franc. Valesius, Lambert Danaeus, Levinus Lemnius, Thomas Lydiat, Conradus Aslacus, Otto Casmannus; who have not doubted to asseverate that the seeds of true Philosophy are conteined in the holy Book of the Bible, and to derive their maximes of Philosophy from thence (though with different successe).
\end{abstract}

This list overlaps to a large extent with the "most Christian men" hailed by Alsted in his Triumphus bibliorum (1625) and with the "Mosaic and Christian philosophers" named in Brucker (though Lydiat is unique to Comenius's list). ${ }^{19}$ All such lists are admittedly artificial constructs, which may well have served as sources one for the next, and they lend a posthumous aura of coherence to a group of authors active independently of one another across Europe, from Spain to Denmark, between 1566 and 1613. Nonetheless, these constructions of a category have some basis in the work of the authors themselves. The later ones cite their predecessors: Aslakssøn (Aslacus) cites Daneau, Casmann cites Daneau and Lemnius, and Lydiat cites Vallès. Four of the six used the phrase "Christian philosophy" or a variant to describe their work (the exceptions being Lydiat and Lemnius). Printers also associated Vallès and Lemnius by publishing their work together. Comenius is not known to have had direct contact with any of these authors, although his enthusiasm for

\footnotetext{
${ }^{18}$ Comenius, Naturall Philosophie Reformed by Divine Light, sig. A6r; and Francis Bacon, New Organon, trans. Fulton H. Anderson (Indianapolis: Bobbs-Merrill, 1960), bk. 1, aph. 89, p. 88; aph. 65, p. 62. In discussing the last passage, Arnold Williams suggests that Bacon may have in mind Hieronymus Zanchi, an Italian converted to Calvinism, whose hexameral commentary (De operibus Dei intra spacium sex dierum creatis opus [1591]) argues for a correspondence between the work of the days of creation and the eight books of Aristotle's Physics, or Lambert Daneau, whom I discuss below. See Arnold Williams, The Common Expositor: An Account of the Commentaries on Genesis, 1527-1633 (Chapel Hill: Univ. North Carolina Press, 1948), p. 176. In addition, an anonymous referee for Isis has pointed out to me that "Paracelsian writers have also been suggested as Bacon's targets in this passage."

${ }^{19}$ Comenius, Naturall Philosophie Reformed by Divine Light, sig. A5v-A6r; for the Latin original ("Christianissimi Philosophi”) see Comenius, Physicae ad lumen divinum reformatae synopsis (1633) (cit. n. 14), sig. b5r. For the lists of Alsted and Brucker see notes 11 and 8, above.
} 
Aslakss $\emptyset$ can be dated to his reading of the latter's Physica et ethica mosaica (1613) shortly after its publication. ${ }^{20}$ (See Figure 3.) Comenius's list is most useful in shedding light on his own agenda, for which he sought to impart a respectable pedigree, and in highlighting what he perceived as a collective program, already under way, for building a new "Christian physics."

Comenius's list spans an impressive variety of authors. Francisco Vallès (1524-1592) was the well-rewarded physician of Philip II who, after publishing numerous medical works and commentaries on Aristotle, Hippocrates, and Galen, explains in the preface to his Of the Things Which Are Written about Physics in the Holy Scriptures; or, De sacra philosophia (1587) that he would devote the rest of his life to a commentary on the Bible "because I think there is no other way to have something certain about natural things and because somehow this reading, even historical or physical, fills my soul with piety.... Until now I have written philosophically, for opinion, but [this book] is written for truth." 21

Levinus Lemnius (1505-1568), a Dutch doctor, is best known for his widely printed and translated On the Secret Marvels of Nature, which exalts the power of God in the occult phenomena and qualities that he catalogues there; but what Comenius has in mind is most likely Lemnius's Clear Explanation of the Comparisons and Parables Concerning Herbs and Trees Which Are Selected from the Bible, first published separately in 1566 and in a number of re-editions, but also consistently published with Vallès's Sacra philosophia in the seven editions of that work from 1587 to $1667 .{ }^{22}$

Lambert Daneau (1530-1595), a Calvinist theologian and minister, active in Geneva and then in Leiden and Béarn, composed a Physica christiana in two parts (1576 and

\footnotetext{
${ }^{20}$ For an example of Casmann's citations see Otto Casmann, Philosophiae et christianae et verae adversus insanos hostium eius et nonnullorum hierophantarum morsus et calumnias modesta assertio (Frankfurt: Palthenius, 1601), Vol. 1, ch. 24 ("De Christiana physica"), p. 153: "Moses enim in rerum genesi totius admirandam spirat naturae explicationem, adeo ut Christianae physicae autor Danaeus physicam generalem ex s. Literarum adytis plene peti posse affirmet." For Aslakssøn's citations of Daneau see Conrad Aslacus, Physica et ethica mosaica (Hanau: Wechel, 1613), pp. 45 (where Daneau serves as a source for references among the Church Fathers), 125 (where Daneau is praised for his "most true opinion" on the creation of the heavens and earth); Aslakssøn also cites Zanchi regularly. Lydiat cites Vallès (along with Cardano, Scaliger, Agricola, and Jean Bodin) among those whose refutation of the Aristotelian theory of the origin of underground springs he praises, but Vallès is not mentioned for his specifically pious agenda; see Thomas Lydiat, Praelectio astronomica de natura coeli et conditionibus elementorum: Item disquisitio physiologica de origine fontium (London: Ioannes Bill, 1605), pp. 83, 91. On Comenius's reading of Aslakssøn see Blekastad, Comenius (cit. n. 13), p. 31. He might have met Lydiat in England, but I have found no specific evidence of this.

${ }^{21}$ On an earlier work of Valles's see José María López Piñero and Francisco Calero, Los temas polemico de la medicina renacentista: Las "Controversias" (1556) de Francisco Valles (Madrid: Consejo Superior de Investigaciones Científicas, 1988). Franciscus Vallès, De iis quae scripta sunt physice in libris sacris, sive de sacra philosophia (1587; Lyon: Franciscus Le Fevre, 1588), pp. 6-7: "Cum quoniam nulla alia ratione censeo certi quidpiam de naturalibus haberi posse, tum quia nescio quo modo eorum lectio, etiam historica, aut physica, animum pietate imbuit latenter. Quare huic lectioni, consecrare senectutem, aequum est putare, scripta esse mihi hactenus Philosophica, ad opinionem, haec autem scribi ad veritatem."

${ }^{22}$ See Jean-Claude Margolin, "Vertus occultes et effets naturels d'après les Occulta naturae miracula de Levinus Lemnius," in L'uomo e la natura nel Rinascimento, ed. Luisa Rotondi Secchi Tarugi (Milan: Nuovi Orizzonti, 1996), pp. 415-443; and Carel Maaijo van Hoorn, Levinus Lemnius, 1505-1568 (Kloosterzande: Duerinck-Krachten, 1978). Vallès's De iis quae scripta was published with Levinus Lemnius, Similitudinum ac parabolarum quae in Bibliis ex herbis atque arboribus desumuntur dilucida explicatio, and Franciscus Rueus, De gemmis aliquot, iis praesertim quarum divus Iohannes Apostolus in sua Apocalypsi meminit, in most editions, including Turin, 1587; Lyon, 1588, 1592, 1595, 1622, 1652; and Frankfurt, 1667. Lemnius's study of the plants in the Bible appeared separately in Antwerp in 1566 and 1568; in Erfurt in 1581; in Frankfurt in 1591; in Lyon in 1594; and in Frankfurt in 1596, 1608, and 1626; and in English translation as An Herbal for the Bible, trans. Thomas Newton (London: Edmund Bollifant, 1587).
} 


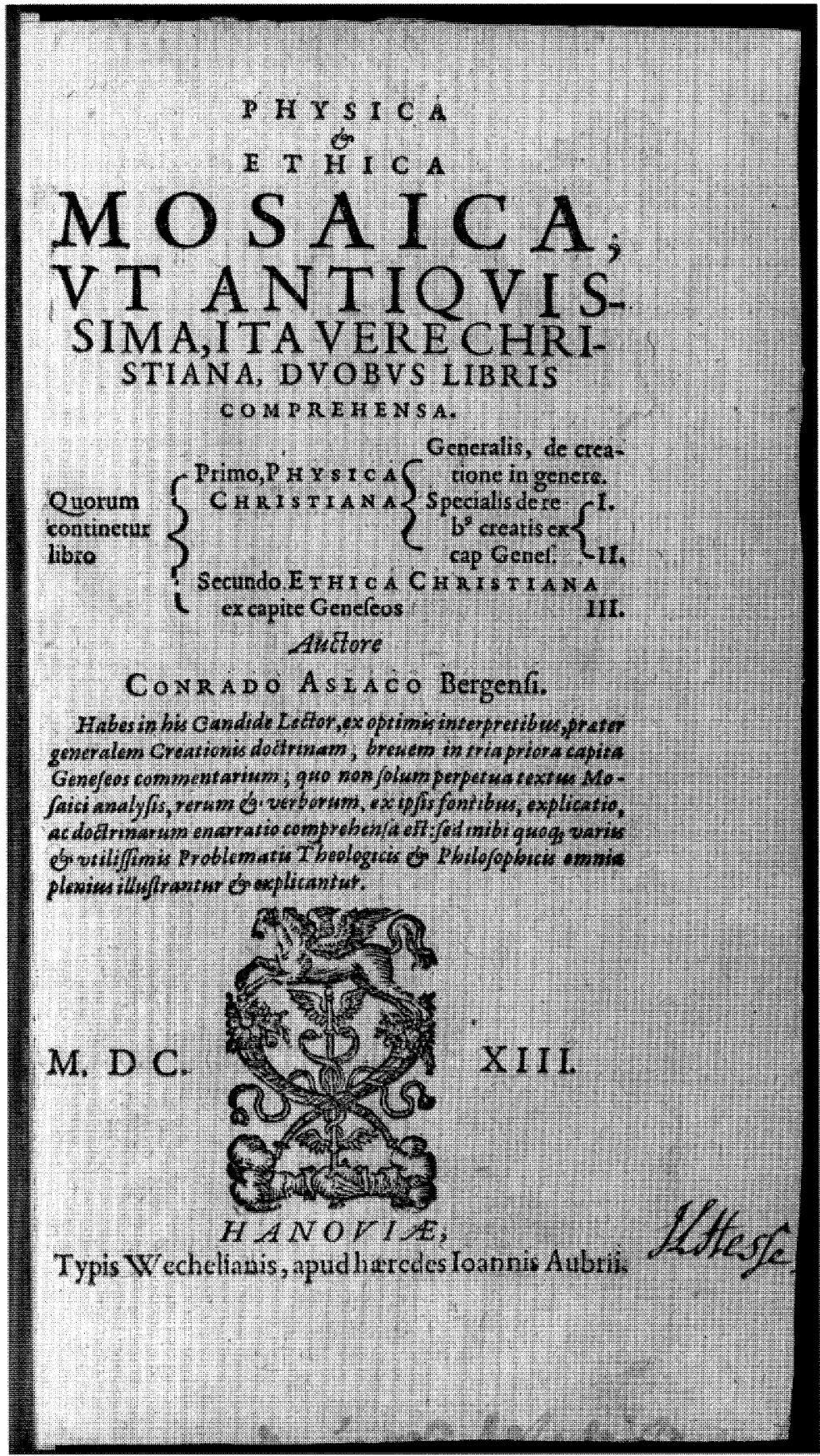

Figure 3. Title page from Conrad Aslacus (Kort Aslakssøn), Physica et ethica mosaica (Hanau, 1613). By kind permission of the Andover-Harvard Theological Library, Harvard Divinity School. 
1580). The first part presented the principles of "Christian physics" and the second a hexameral commentary on the natural phenomena described in the Bible. ${ }^{23}$

Otto Casmann (1562-1607) taught philosophy at the new Calvinist gymnasium in Steinfurt in Germany (preceding Clemens Timpler there), then moved on to the rectorship of the new school in Stade. He published numerous treatises, including, for example, Cosmopoeia et ouranographia christiana, an account of the world and the heavens that hailed not reason but the sacred word of God as its first foundation, and the treatise Alsted mentions, his Ethica et oeconomica theosophica (1602). But Casmann also defended the use of philosophy, in particular against those (whom, unfortunately, he does not name) who would eliminate the discipline altogether, to judge from a combative defense of Christian philosophy entitled A Modest Assertion of the Philosophy Both Christian and True against the Crazy Bites and Calumnies of Its Enemies and Some Hierophants (1601). ${ }^{24}$

Conrad Aslacus, or Kort Aslakssøn (1564-1624), originally from Bergen (Norway), was professor of theology at Copenhagen and the author of Physica et ethica mosaica (1613), which systematizes in the Ramist style the principles of Mosaic physics and the commentary on Genesis that it comprises. ${ }^{25}$

Thomas Lydiat (1572-1646), a mathematician who lectured on astronomy at Oxford and is best known for his involvement in disputes over chronology with Joseph Scaliger and Christopher Clavius, is the biggest surprise on Comenius's list and does not figure on other lists of "Christian philosophers." Nonetheless, Comenius is not entirely misguided in including him, given the interests he expressed in an early academic work. In his Praelectio astronomica and Disquisitio physiologica of 1605 , conceived at the university six years earlier, Lydiat explains that he

tried, after refuting the opinions of Aristotle especially on the nature of the heavens and elements, to give physical reasons for that constitution of the universe ... which seems to be reported in the sacred Scriptures, according to the genuine interpretation of them accepted even today by most Christians and in the old days by all Christians, before the minds of some of them were carried away to foreign interpretations by the arguments of the pagan philosophers, especially the Aristotelians or Peripatetics; and to do this with special attention to demonstrating that the same is true physically and theologically.

${ }^{23}$ Lambert Daneau, Physica christiana (Geneva: Petrus Santandreanus, 1576); and Daneau, Physicae christianae pars altera (Geneva: Vignon, 1580). The first part appeared again in Geneva in 1579, 1580, 1588, 1602, and 1606 and in an English translation as The Wonderfull Woorkmanship of the World, trans. T[homas] T[wyne] (London: Andrew Maunsell, 1578); the second part appeared again in Geneva in 1582, 1589, and 1606. See Olivier Fatio, Méthode et théologie: Lambert Daneau et les débuts de la scolastique réformée (Geneva: Droz, 1976), and reproductions of the title pages of these works, pp. $161^{*}-164 *, 177^{*}-178^{*}$.

${ }^{24}$ Otto Casmann, Cosmopoeia et ouranographia christiana (Frankfurt: Palthenius, 1598), p. 58 (see also note 11, above): "Nos ratione non nitimur, ut primo fundamento, sed Dei sacro verbo." Casmann, Philosophiae et christianae et verae adversus insanos hostium eius et nonnullorum hierophantarum morsus et calumnias modesta assertio (Frankfurt: Palthenius, 1601). Brucker describes this work as Casmann's response to criticism of his earlier Biographia (cit. n. 11); see Brucker, Historia critica (cit. n. 7), Vol. 4, p. 615. On Casmann and his general academic context see Joseph Freedman, European Academic Philosophy in the Late Sixteenth and Seventeenth Centuries: The Life, Significance, and Philosophy of Clemens Timpler (1563/4-1624), 2 vols. (Hildesheim: Olms, 1988), esp. Vol. 1, p. 54.

${ }^{25}$ I use "Aslakssøn" when referring to the historical figure but "Aslacus" in bibliographical citations, following my primary sources. On Aslakssøn (also Axelson) see Jole Shackelford, "Rosicrucianism, Lutheran Orthodoxy, and the Rejection of Paracelsianism in Early Seventeenth-Century Denmark," Bulletin of the History of Medicine, 1996, 70:181-204, on pp. 188-192; and Shackelford, "Unification and the Chemistry of the Reformation," in Infinite Boundaries: Order, Disorder, and Reorder in Early Modern German Culture, ed. Max Reinhart (Sixteenth-Century Studies and Essays, 40) (Kirksville, Mo.: Sixteenth-Century Journal Publishers, 1998), pp. 291312, esp. pp. 299-302. I am grateful to the author for these references and for copies of these articles. 
The two treatises argue for two hypotheses "against the opinion of many Christians now excessively addicted to gentile, especially Peripatetic philosophers": first, "that there is an enormous mass of supercelestial waters, cause of the first motion etc.," and, second, "a great abundance of fire below the earth, cause of eternal springs, etc." ${ }^{26}$ In his arguments against Aristotelian explanations in meteorology and cosmology (from fiery or watery exhalations or the nature of a fifth, heavenly element, which Lydiat rejects), Lydiat adduces philosophical authorities and reasoning but in concluding emphasizes the authority of the Bible. Notably, in his final chapter Lydiat cites the Bible abundantly to support his conclusions, and Comenius seizes on his closing passage to claim as an ally an author who probably more than the others on the list held status among contemporary practitioners of natural philosophy (as quoted below, p. 51).

Comenius's list did not exhaust the full range of authors who might be considered "Christian philosophers." Brucker includes among the "Mosaici et Christiani" Johann Heinrich Alsted, whom Comenius praises as his teacher and whose Triumphus bibliorum he acknowledges as an important source for his own work of natural philosophy. In a series of short chapters covering all the disciplines (in a scheme very similar to that developed in his Encyclopedia of 1630), Alsted provides biblical examples and precepts of piety to define a "sacred" version of each discipline, from the liberal arts to the higher faculties. In addition, in the Encyclopedia Alsted devotes an independent book to the "Physics of Moses, David and Job." Other authors could be added as well. I have argued elsewhere that Jean Bodin, although hardly a "Christian," was nonetheless a pious philosopher in the Mosaic vein: he repeatedly resolved disputed natural philosophical questions from biblical authority confirmed by rational arguments and characteristically both used reason to prove central religious tenets and narrowed the purview of reason by acknowledging its limitations. ${ }^{27}$ Paracelsians, Behmenists, and other theosophical thinkers like Robert Fludd, author of a Philosophia moysaica (1638) that appeared after Comenius first composed his work, might also have been included, as they were among Morhof's Mosaic philosophers. Certainly the categories of explanation they proposed, with their emphasis on spirit and light and chemical principles, offered appealing alternatives to Aristotelian theory, which surface in the biblical physics of Comenius and Alsted especially.

We are reduced to speculating about the reasons for Comenius's particular selection of "most Christian philosophers." Bodin may have seemed to emphasize reason too much in providing demonstrations for religious truths; Fludd and the Paracelsians perhaps wandered too freely away from the Bible, as Brucker explains in distinguishing them from the "Mo-

\footnotetext{
${ }^{26}$ Lydiat, Praelectio astronomica (cit. n. 20), sig. [A5]r-v: "Igitur his duabus exercitationibus Philosophicis, ante sexennium in Academia conceptis, conatus sum, refutatis praesertim Aristotelis opinionibus de natura coeli et elementorum, reddere rationes Physicas illius constitutionis universi (quoad maiores ipsius partes et potissimas harum affectiones) quae sacris scripturis videretur esse tradita iuxta genuinam earum sententiam, a plerisque Christianorum etiam hodie, ab omnibus vero olim receptam antequam quorundam mentes Ethnicorum Philosophorum praesertim Aristotelicorum sive Peripateticorum argutijs inescatae ad alieniores interpretationes abducerentur: id praecipue operam dans ut demonstrarem idem esse verum Physice ac Theologice." Ibid., p. 181: "Eoque magis quodum in duabus hisce commentatiunculis duas hypotheses aliquantum praeter multorum Christianorum nunc nimis addictorum Philosophis ethnicis praesertim Peripateticis opinionem statuerimus; alteram quidem, ingentem esse aquae vim supra coelum, causam primi motus etc. alteram vero, magnam esse ignis copiam infra terram, causam fontium perennium etc." See Mordechai Feingold, The Mathematicians' Apprenticeship (Cambridge: Cambridge Univ. Press, 1984), pp. 48-49, 55-56, 146-152; Anthony Grafton, Joseph Scaliger: A Study in the History of Classical Scholarship (Oxford: Clarendon, 1993), Vol. 2, pp. 744-745; and W. H. Donahue, “A pre-Keplerian oval orbit,” Journal for the History of Astronomy, 1973, 4:192-194.

${ }^{27}$ Ann Blair, The Theater of Nature: Jean Bodin and Renaissance Science (Princeton, N.J.: Princeton Univ. Press, 1997), esp. ch. 4. For an analysis of Bodin's Judaizing tendencies see Paul L. Rose, Bodin and the Great God of Nature: The Moral and Religious Universe of a Judaiser (Geneva: Droz, 1980).
} 
saici." Or, more pragmatically, perhaps none of them was orthodox enough to enhance the standing of Christian philosophy among a broader, mainstream audience, which was no doubt part of Comenius's purpose in this work. Comenius certainly adopted a number of Paracelsian, alchemical, and hermetic ideas in his natural philosophy. He identifies the three chemical principles and emphasizes a triad of principles of his own: matter as the principle of being, spirit the principle of life, and light the principle of motion. Comenius also supports atomism from biblical references to primordial dust in Genesis and Job. But, as Jaromír Červenka points out, Comenius cites primarily Juan Luis Vives, Tommaso Campanella, and Francis Bacon rather than more controversial Paracelsian or atomist sources. ${ }^{28}$ In outlining the specifics of his physics, Comenius draws on a variety of different philosophical systems available at the time, including Aristotelianism, which he does not completely abandon. The originality of his "Christian physics" is more evident in the lengthy theoretical preface about his project than in the particular combination of existing explanatory elements that he offers in the body of the text. Indeed, in looking at what Comenius's "Christian philosophers" have in common, it is easier to identify "Christian philosophy" as a set of shared theoretical tenets than as a uniform system of natural philosophical explanation.

\section{THE TENETS OF “PIOUS PHILOSOPHY”}

\section{The Unity of Knowledge}

Above all, Comenius's "most Christian philosophers" have in common a desire to construct a new natural philosophy, freed from a slavish adherence to the authority of Aristotle, Plato, and every other philosopher (including Petrus Ramus or Jacopo Zabarella, as Casmann adds pointedly), and beholden instead to truth, which is found through reason but especially in the sacred authority of Scripture. Lydiat explicitly repeats the refrain, common in various forms to many Renaissance thinkers: "amicus Socrates, amicus Plato, sed maxime amica veritas" (Socrates is a friend, Plato is a friend, but truth is the greatest friend). ${ }^{29}$ Across their different backgrounds (Catholic, Lutheran, and a preponderance of Calvinists), these authors proposed a firm rejoinder to the doubts of both philosophers and theologians, in the wake of unsettling innovations in the two fields, as to the very possibility of a harmonious synthesis between philosophy and theology. If the concept of a "double truth" was rarely advanced explicitly by any philosopher, it was nonetheless perceived as the dangerous presupposition of extremists on both sides: of philosophers like Pomponazzi, on the one hand, who seemed to deny the immortality of the soul, and of theologians in the strict descendance of Luther, on the other hand. In the latter vein, Daniel Hofmann, a professor of theology at the University of Helmstedt in the 1580s and 1590s, sought to stop the teaching of philosophy altogether on the grounds that philosophical conclusions contradicted theological ones. Against these two kinds of enemies, the pious philosophers

\footnotetext{
${ }^{28}$ For the principles see Comenius, Naturall Philosophie Reformed by Divine Light (cit. n. 14), esp. chs. 2 and 4. Comenius's physics is neatly reduced to thirty-three propositions in Brucker, Historia critica (cit. n. 7), Vol. 4, pp. 641-643, here proposition 23. For the references to primordial dust see Comenius, Naturall Philosophie Reformed by Divine Light, pp. 28, 30, discussed in Danton B. Sailor, "Moses and Atomism," Journal of the History of Ideas, 1964, 25:3-16, on pp. 8-9. On Comenius's citations see Červenka, Naturphilosophie des Comenius (cit. n. 10), pp. 63-64.

${ }^{29}$ Casmann, Philosophiae ... modesta assertio (cit. n. 20), p. 55; and Lydiat, Praelectio astronomica (cit. n. 20), sig. A4r. On this saying, ancient in origin but especially in vogue in the Renaissance, see Leonardo Tarán, "Amicus Plato sed magis amica veritas: From Plato to Aristotle to Cervantes," Antike und Abendland, 1984, 30:93-124; and Henry Guerlac, “Amicus Plato and Other Friends," J. Hist. Ideas, 1978, 39:627-633.
} 
emphasized the unity of philosophical and religious truth, which guaranteed both a role for philosophy and a generally increased role for the Bible.

As their largely self-assigned title indicates, the "Christian philosophers" were committed to the alliance between piety and philosophy and the rejection of any notion of double truth. For Casmann, "the double truth of one and the same thing, one theological, of divine wisdom, the other philosophical, of human wisdom, is a devilish figment very convenient to excuse and defend all errors and atheisms. The truth is one and simple, and always similar to itself: but the false is multiple and always dissimilar to itself." Lydiat rejected the separation of theological and physical truth as "what is commonly done." 30 The strategies that Comenius's "Christian philosophers" proposed for unifying knowledge differed, as I will later discuss in more detail- "Christian philosophy" was often more effective as an agenda than as a practice. The principal strategies were to offer a natural philosophical commentary on the Bible or to draw new principles of physics from the Bible. But whatever strategy one took, the ideal of showing the unity of philosophy and theology was a long-traditional agenda with medieval origins, reinvigorated at the Fifth Lateran Council by the call to philosophers to demonstrate religious truths; it acquired a new urgency in the context of the late Renaissance during the decades of religious wars and increasing confessionalism. In this setting of intense disarray, the pious philosophers thought they could provide, by relying on "sense, reason and Scripture," a single, indubitable truth for everyone everywhere, to unite all confessions and philosophical schools.

\section{The Role of Philosophy}

Although their recourse to the Bible as the only certain and most ancient authority may seem to us deeply unphilosophical, the Christian philosophers were committed to both parts of their label, to the possibility of uniting piety with philosophical learning. Thus Casmann warns of two dangers: on the one hand, he fears the threat posed by

those who because of the few things which they see with their eagle eyes differ in the books of the pagan philosophers from the decrees and sanctity of our religion, reject not only all the other very numerous true and useful things transmitted by [those philosophers], but also slander and calumny the Christian knowledge of any philosophy and call for it to be eliminated from the society of men, especially of Christians, like a plague.... [On the other hand] the second threat is of those who admire and embrace the divine talents, as they call them, of Plato and Aristotle, ... so that these worshippers of men (anthropolaters and prosopolaters) embrace them with such assent of mind, as if they were divinities and gods free from the errors of philosophy, that they can hardly believe that something might be proven which they had disproved or something disproved which they had proven. ${ }^{31}$

${ }^{30}$ Casmann, Philosophiae ... modesta assertio, p. 40: "Duplex vero illa veritas unius eiusdemque rei, una Theologica sapientiae divinae, altera Philosophica, sapientiae humanae, est diabolicum ad omnes errores atque atheismos excusandos et defendendos accommodatissimum figmentum. Verum unum ac simplex, suique perpetuo simile: falsum autem multiplex, suique perpetuo dissimile." Lydiat, Praelectio astronomica, sigs. A4vA5r: "Haudquaquam ratus oportere me contentum esse eo quod vulgo solitum esset responderi ad huiusmodi dogmata Aristotelica sententiae sacrorum bibliorum contraria, scilicet verum est Physice non Theologice."

${ }^{31}$ Casmann, Philosophiae ... modesta assertio, sigs. 2r-v, 3v: "Primum genus dico eorum qui propter pauca, quae in libris paganorum philosophorum, a decretis et sanctitate nostrae religionis abludere et aliena aquilinis cernunt oculis, non modo cetera quam plurima vere et utiliter ab illis tradita reiiciunt, sed omnem etiam cuiusvis Philosophiae Christianam cognitionem rodunt, calumniantur, ac tanquam certam animorum pestem, ex hominum praesertim Christianorum societate exterminandam iudicant, clamant. ... Alterum genus est eorum qui divina ut vocant Platonis et Aristotelis ingenia, uberrimamque cunctarum rerum scientiam cum excellenti eloquentia coniunctam, usque eo admirantur et amplexantur, ut eos veluti numina et Deos a lapsibus immunes philosophiae, tanquam anthropolatrae et prosopolatrae adorent, eorumque decreta Philosophica, tanta animi assensione complectantur, vix ut credant, quicquam esse posse probabile, quod improbetur ab illis, aut quod ab illis probetur, improbabile." 
Historians are well aware of the fears of excessive philosophical naturalism that Casmann shared with many contemporaries. But they have generally not attended to the other threat that Casmann perceives, which stems from a theological camp that wanted to eliminate philosophy altogether.

In the early years of the Reformation (ca. 1519-1522) Martin Luther had called for the elimination of Aristotelian philosophy from the arts curriculum; but by midcentury Philip Melanchthon's pedagogical reforms had largely reinstated philosophy as a central discipline and Aristotle as the dominant authority in the textbooks and teaching of Lutheran universities. ${ }^{32}$ In the 1580s and 1590s, then, Daniel Hofmann (1538-1621) was rebelling against established pedagogical practices when he renewed Luther's original call to eliminate philosophy from the curriculum. After teaching philosophy himself at the newly founded University of Helmstedt from 1576 to 1578, Hofmann became professor of theology there. He grew increasingly hostile toward the philosophers at Helmstedt, who were mostly humanist and Philippist in orientation. In particular, Hofmann combatively maintained that even the best use of philosophy was contrary to theology. Despite rallying a few supporters at Helmstedt, the "Hofmannian controversy" he generated ended with his dismissal from the university after a public apology to the philosophers in 1601. His attempts at modifying the curriculum had failed. But Hofmann inspired a few former students to pursue his line of argumentation in the 1620s in Magdeburg, among them Johann Angelius Werdenhagen, Wenceslaus Schilling, and Andreas Cramer, who spearheaded the "Controversia crameriana magdeburgensis." Although the antiphilosophical stance championed by Hofmann and his followers was never implemented, it embodied a continued threat that seemed serious to contemporaries and early modern historians. Brucker, for example, closes his survey of seventeenth-century thinkers with a chapter on the "enemies of philosophy" that is devoted primarily to the "Hofmann controversy." 33 The theological opposition to philosophy never spread beyond a narrow group of extreme Lutherans, but in the German area it kept alive the threat of a return to Luther's own original position.

The fear of a theology hostile to philosophy was also alive elsewhere, even outside the Lutheran context. Thus Robert Boyle can be found implying that dangerously antiphilosophical clerics exist and that their impact is to be deplored. As in the case of "atheists," who were regularly reviled in the sixteenth century even though hardly any were clearly identified, one can conclude that the specter of a much-feared enemy (here, theologians who would reject philosophy) galvanized a preventive defensive strategy. The Christian

\footnotetext{
${ }^{32}$ This story is the subject of Sachiko Kusukawa, The Transformation of Natural Philosophy: The Case of Philip Melanchthon (Cambridge: Cambridge Univ. Press, 1995); see p. 39 ff. on Luther's hostility to Aristotelian philosophy.

${ }^{33}$ On Hofmann see Maria Rosa Antognazza, "Hofmann-Streit: Il dibattito sul rapporto tra filosofia e teologia all'Università di Helmstedt," Rivista Filosofica Neoscolastica, 1996, 86:390-420, esp. pp. 393-397, 410. I owe this reference to Markus Friedrich, to whom I am grateful for helpful advice. He is preparing a dissertation at the University of Munich on the controversies at Helmstedt and Magdeburg and the antiphilosophical stance more generally, under the working title "Die Grenzen der Vernunft: Theologie, Philosophie und die doppelte Wahrheit zwischen Helmstedt und Magdeburg um 1600." See also the entries on Hofmann in Bayle, Dictionnaire historique et critique (cit. n. 13), and Allgemeine Deutsche Biographie, 2nd ed. (Berlin: Duncker \& Humblot, 1967-1971), Vol. 12, pp. 628-629; and William Ashford Kelly, "The Theological Faculty at Helmstedt: An Outline of Its Intellectual Development as Mirrored in Its Dissertations, Together with a Chronological Catalogue" (Ph.D. diss., Univ. Strathclyde, 1991), esp. pp. 101-105. On Hofmann's students see the entries on Cramer, Schilling, and Werdenhagen in Allgemeine Deutsche Biographie, Vol. 4, pp. 545-546, Vol. 31, pp. 261-262, and Vol. 41, pp. 759-762, respectively; and Peter Petersen, Geschichte der aristotelischen Philosophie im protestantischen Deutschland (Leipzig: Felix Meiner, 1921), pp. 263-267. See also Brucker, Historia critica (cit. n. 7), Vol. 4, Pt. 1 bk. 3, ch. 5, “De hostibus philosophiae," pp. 776-785.
} 
philosophers felt that the best way to defend philosophy against these theological attacks was to make it more pious. Thus Casmann called for the liberation of philosophy from its excessive indebtedness to ancient (or, more rarely, modern) authority. Lydiat too warned of a "peripatetic theology" that Christians were embracing as if it were a religious doctrine. ${ }^{34}$ The point of mocking slavish Aristotelians was not to do away with philosophy altogether but, rather, to save it, notably from the attacks of theologians, by making it thoroughly pious and true.

\section{The Role of the Bible}

Finally, the pious philosophers agreed on reading the Bible for its statements about nature. Vallès explains this position against detractors:

I am persuaded that these Scriptures were written by human friends of God inspired by the Holy Spirit, and very little for the interpretation of nature.... Nonetheless since some natural questions are woven into the line of discussion, I believe that they are all very true, since they are dictated by the spirit of God, the absolute embodiment of truth, and flow from the author of nature himself, for whom nothing can be hidden. . . . For these reasons I persuade myself and want all to be persuaded that there is a whole other doctrine, which is true, contained in these divine books - that is a natural one. ${ }^{35}$

Vallès turns the argument that the Bible's purpose is religious rather than philosophical on its head: since God had no need to introduce natural questions in the Bible, when he does so these statements should be taken seriously. As a result, Vallès concludes that the Bible contains truths of natural philosophy as well as other disciplines.

In looking for natural philosophical truths, Comenius's Christian philosophers read the Bible literally rather than in the more allegorical ways favored by Paracelsians and hermetic philosophers. The new literalism that emphasized the historical, geographical, and scientific information contained in the Bible has been identified as a Protestant phenomenon; thus English preachers were directed in manuals like that of John Wilkins to a number of works that would explicate "Scripture philosophy" and "Scripture geography," among them those of Vallès, Lemnius, and Rueus. But as that combined publication indicates, the new literalism also found favor with Catholics. The Jesuit theologian Benito Pereira, in articulating the principles of biblical hermeneutics for the Counter-Reformation Church,

\footnotetext{
${ }^{34}$ Lydiat, Praelectio astronomica (cit. n. 20), p. 53, speaking of the Aristotelian belief in the existence of heavenly intelligences: "Tantidem Intelligentiarum Aristotelicarum existentiae, adeoque toti Theologiae Peripateticae (ut sciant nostri christiani quam religiosam doctrinam amplectantur) derogatum esse intelligite." Notably, Boyle wrote in 1665 to the Presbyterian minister Richard Baxter that he was glad that "you [are] none of those narrow-souled divines, that, by too much suspecting natural philosophy, tempt many of its votaries to suspect theology": Robert Boyle, Letters, in The Works of the Honourable Robert Boyle, 2nd ed. (London: Rivington, 1772), Vol. 6, p. 520, cited in Hooykaas, Robert Boyle (cit. n. 2), p. 57. The debate on the existence of atheists in the sixteenth century continues; for the most recent discussion and literature see Michael Hunter and David Wootton, eds., Atheism from the Reformation to the Enlightenment (Oxford: Clarendon, 1992); and Silvia Berti, "At the Roots of Unbelief," J. Hist. Ideas, 1995, 56:555-577.

${ }^{35}$ Vallès, De iis quae scripta (cit. n. 21), pp. 5-6: "Ego divina haec eloquia, minime ad naturae interpretationem scripta esse, a viris Dei amicis, sancto afflatis spiritu, mihi persuadeo... Tamen, cum quaedam in ipso sermonum ductu texantur naturalia, ea omnia verissima esse existimo, utpote quae, a summe vero Dei spiritu, dictata sint, et ab ipso naturae autore fluxerint, quem latere nihil potuit. . . Ob haec ego mihi persuadeo atque omnibus persuasum volo, ut omnem aliam doctrinam, quae vera sit, ita naturalem, in his divinis libris contineri."
} 
started with the principle that the Mosaic account is historical and should be read as such. ${ }^{36}$ Comenius's "Christian philosophers" commonly complained that the meaning of the Bible had been distorted (literally, "tortured") to fit the opinions of pagan philosophers, especially the Peripatetics. Thus Lydiat complained of the many contemporaries who denied the existence of supercelestial waters: "[by] twisting the words of holy Scripture to the meaning of the pagan philosophers, especially the Peripatetics, they decide that these waters pour forth from what is commonly called the middle region of the air in which clouds form." Casmann gave a resounding negative to the question of whether "on physical matters the sacred oracles should be tortured to fit the common rules of Aristotelian physics." Aslakss $\varnothing$ n, too, found nothing more absurd than applying an exclusively allegorical interpretation to the first three chapters of Moses, which should instead be read literally in the first instance. ${ }^{37}$

As the word of God, the Bible was inevitably the most sacred and highest authority. These philosophers also highlighted its great antiquity and its encyclopedic store of truth. For Comenius, the divine writings are "like an universal treasury of wisdome." Lydiat, concluding his Disquisitio physiologica with a chapter on the Flood, hails the Bible as a neglected source of information in a passage that Comenius quotes enthusiastically: "And piously T. Lydiat: 'It is most absurd, that heathen Philosophers should seek for the principles of all arts in one Homers poesie, and that we Christians should not do the same in the Oracles of God, which are a most plentifull and most clear fountain of wisdome.' " Similarly, Aslakss $\varnothing \mathrm{n}$ calls on Christians to read and meditate on the unique and inexhaustible treasury of the sacred writings of the prophets and apostles, with even more diligence than the pagan philosophers studied their philosophical authorities. And Lemnius praises the Bible as a source of "plentiful knowledge and copious learning" and of more "sovereign food for both soul and conscience" than is to be had from the books of philosophers or orators and poets. ${ }^{38}$ Drawing from such a vast treasury of knowledge, pious philosophy

\footnotetext{
${ }^{36}$ For the Vallès-Lemnius-Rueus edition see note 22 , above. On the varieties of interpretive approaches to both the Bible and nature in the Renaissance see James J. Bono, The Word of God and the Languages of Man: Interpreting Nature in Early Modern Science and Medicine, Vol. 1: Ficino to Descartes (Madison: Univ. Wisconsin Press, 1995), e.g., pp. 82-84. For the argument that Protestant literalism fostered the development of modern empiricism see Peter Harrison, The Bible, Protestantism, and the Rise of Natural Science (Cambridge: Cambridge Univ. Press, 1998), esp. ch. 4. See John Wilkins, Ecclesiastes; or, A Discourse Concerning the Gift of Preaching (1647; 4th ed., London: Gellibrand, 1653), p. 41, as discussed in Harrison, Bible, Protestantism, and the Rise of Natural Science, p. 126 and n. 20. For other examples of Protestant works on biblical geography and natural history see Otto Zöckler, Geschichte der Beziehungen zwischen Theologie und Naturwissenschaft mit besondrer Rücksicht auf Schöpfungsgeschichte, 2 vols. (Gütersloh: Bertelsmann, 1877-1879), Vol. 1, pp. 563-568. On Pereira see Armogathe, "Physica sacra de Comenius" (cit. n. 14), p. 15.

${ }^{37}$ Lydiat, Praelectio astronomica (cit. n. 20), p. 186: "Verum nostra aetate multi nullas eiusmodi aquas supercoelestes agnoscentes, sed verba sacrae scripturae ad Ethnicorum Philosophorum praecipue Peripateticorum sensus torquentes, ab illa quae vulgo media aeris regio appellatur in qua nube consistunt, effusas esse statuunt." Casmann, Cosmopoeia (cit. n. 24), prolegomenon: "An de rebus physicis sacra oracula ad vulgares aristotelicae physicae regulas sint contorquenda?" Aslacus, Physica et ethica mosaica (cit. n. 20), p. 101: “An quae narrat Moses primis tribus capitibus geneseos sint litteraliter intelligenda? Quantum vero ad sensum trium primorum capitum Gen. attinet, debent haec non tantum allegorice, sed primum litteraliter intelligi. Nec tamen mysticum in quibusdam prorsus reiicimus sensum, dummodo simplex litteralis et historica verborum expositio, non excludatur, sed praesupponatur. Deinde, si primum et secundum caput geneseos allegorice tantum est explicandum. ... imo totum Mosen reliquamque scripturam eodem modo mystice et allegorice tantum explicare licebunt. Quod absurdissimum."

${ }^{38}$ Comenius, Natural Philosophie Reformed by Divine Light (cit. n. 14), sig. a5r. See the original passage in Lydiat, Praelectio astronomica, p. 200 (ch. 10 of the "Disquisitio physiologica"): "Absurdissimum enim existimavimus Ethnicos philosophos in unius Homeri poesi omnium artium principia quaerere: nos vero Christianos in oraculis Dei uberrimo scilicet pariter ac limpidissimo sapientiae fonte non idem facere." On the role of Homer as a source of wisdom see Plutarch's Essay on the Life and Poetry of Homer, ed. Robert Lamberton and John
} 
had encyclopedic potential, as the wide-ranging ambitions of Comenius and Casmann attest.

\section{THE PRACTICES OF "PIOUS PHILOSOPHY”}

The works of Comenius's "most Christian philosophers" were primarily pedagogical in intent. Comenius, Aslakss $ø$, Lydiat, Casmann, and Alsted composed their treatises while teaching at universities or gymnasia, ostensibly with an audience of students and colleagues in mind. Those of the minister Daneau and the physicians Vallès and Lemnius served as an incitement to piety in general and, more specifically, as an aid in the preparation of sermons. This utility-evident, for example, in the citation of Vallès-Lemnius in Wilkins's preacher's manual-probably explains their repeated printings (four of Daneau and seven of Vallès-Lemnius, down to 1667). Without attempting a full study of the reception of these works, one can begin to assess their impact from the texts themselves. The texts are generally forceful in presenting the principles of a "pious" or "Christian" philosophy, but less so in putting that agenda into practice. One often gets the sense that the Christian philosophers found their principles more worthy of attention than the specific conclusions they might generate. In Casmann and Comenius, the principles dominate; similarly, only the first of Daneau's two books, on the principles of Christian physics, was translated into English two years after its Latin publication, although the second, longer volume offered the "contents" of a Christian physics.

In one set of practices, "Christian physics" was a commentary on the references to natural things in the Bible - this is the case with Aslakssøn, Daneau, Vallès, and Lemnius (and Rueus). Aslakssøn covers the first two chapters of Genesis in the physics section of his Physica et ethica mosaica and uses the third as the basis for his section on ethics. (See Figure 4.) Daneau follows the order of the creation story through Genesis 1:24, omitting the creation of humankind. Vallès chooses more varied passages with which to begin each chapter. In commenting, for example, on the laws in Leviticus and Deuteronomy he discusses which pigs have cleft feet, for example (notably those of Illyria), and so are unclean only on one count, that of not ruminating. The Bible provides him with the opportunity to treat a wide range of topics, from salt and its divine associations to demons, leprosy, the role of the number 7 (involved in rules about confinement of the mother after birth), and the power of music (in curing David's melancholy) - all of which one might have found in a non-"Christian" physics and which Vallès discusses using the tools of the philosopher, quoting Avicenna, Galen, Aristotle, and Pliny among other authorities. Lemnius devotes a chapter to each of the plants mentioned in the Bible, which he treats in no apparent order. The mandrake, for example, gets a full natural historical description, with a discussion of popular practices (of carving the root into the shape of human genitals to fool the ignorant and get money from them) that includes the author's description of his personal experience of its soporific powers. He treats at length the biblical references to the mandrake (Rachel desperately wanted some) and especially its appearance in the Song of Songs, amid similes that are praised as most appropriate and beautiful. ${ }^{39}$

J. Keaney (Atlanta, Ga.: Scholars' Press, 1996), which was widely read in the Renaissance. Aslacus, Physica et ethica mosaica, pp. 83-84: "Quod si vero ethnici ethnica sua scripta, tanta vigilantia et assiduitate nocturna diuturnaque manu versare volupe duxerunt: quanto magis Christianos Christianae doctrinae unicum hoc $\kappa \varepsilon \mu \gamma \gamma \lambda$ lov et inexhaustum Thesaurum videlicet Sacrosancta prophetarum et apostolorum scripta assidue evolvere, legere et meditari debebunt." Lemnius, Herbal for the Bible, trans. Newton (cit. n. 22), sig. b3v.

${ }^{39}$ Lemnius, Herbal for the Bible, trans. Newton, ch. 2, pp. 10-20. 


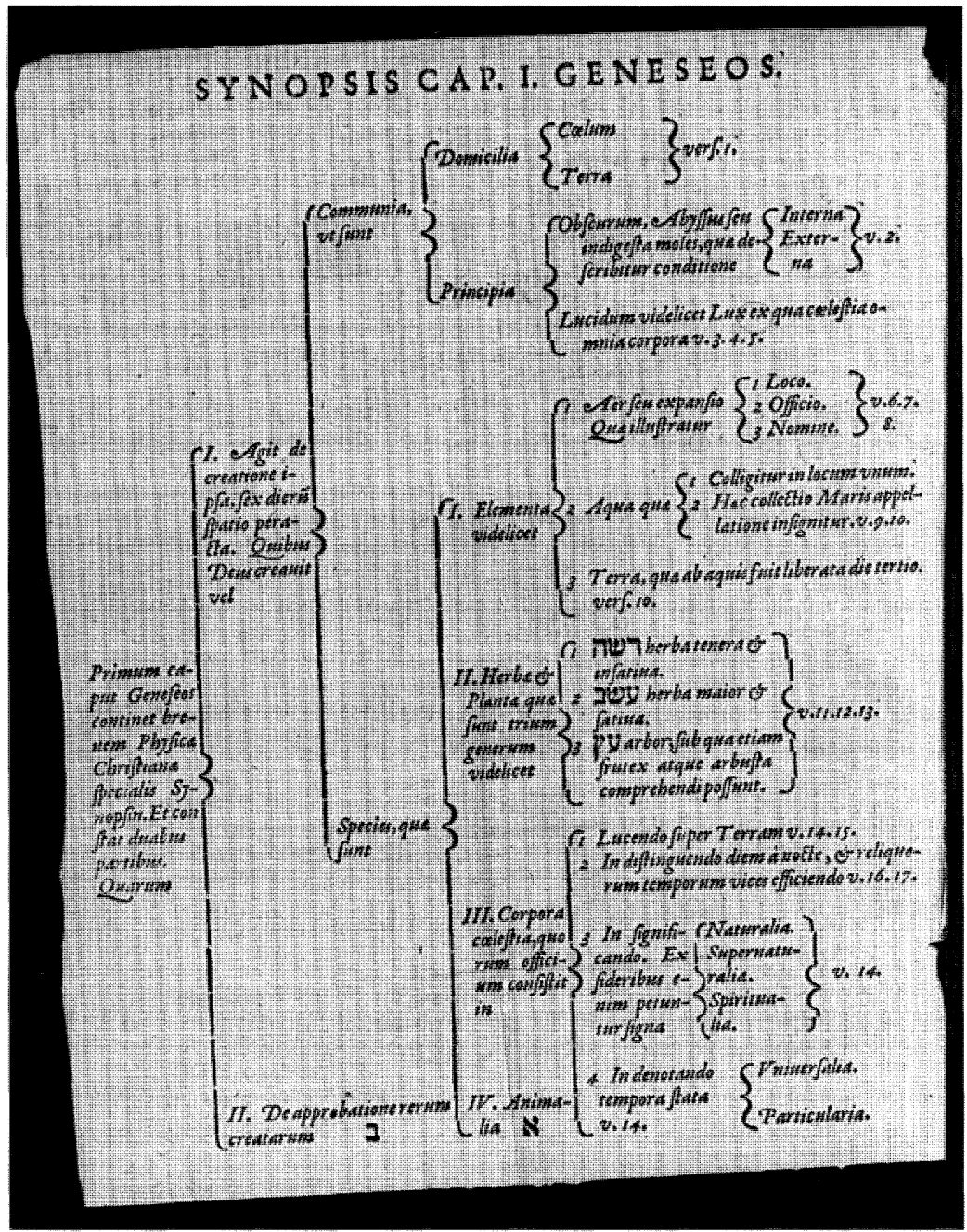

Figure 4. Fold-out diagram from Conrad Aslacus (Kort Aslakssøn), Physica et ethica mosaica (Hanau, 1613). By kind permission of the Andover-Harvard Theological Library, Harvard Divinity School.

In these cases the Bible functions as a text on which to hang relevant commentary, serving much the same purpose as Ovid or Virgil in the Renaissance classroom (or Homer, as Lydiat complained). If it were not for the fact that the authors themselves (in the cases of Vallès, Daneau, and Aslakssøn) or others (for Lemnius) billed their discussions as "Christian philosophy," much of this work could be considered standard Renaissance biblical commentary. ${ }^{40}$ What makes it more than simple biblical commentary is the claim that

${ }^{40}$ For examples of classroom commentaries on Ovid in the Renaissance see Ann Blair, "Ovidius Methodizatus: The Metamorphoses of Ovid in a Sixteenth-Century Paris Collège," Hist. Univ., 1990, 9:73-118; and, more generally, Ann Moss, Ovid in Renaissance France (London: Warburg Institute, 1982); and Latin Commentaries on Ovid from the Renaissance, ed. and trans. Moss (Signal Mountain, Tenn.: Summertown, 1998). For examples of Renaissance biblical commentary see Williams, Common Expositor (cit. n. 18), ch. 9. 
such a study of the Bible yields philosophical truth rather than mere historical knowledge or contextual background for a religious interpretation. The Christian philosophers asserted the truth of Moses's words in a "strictly natural, literal, and philosophical sense" (as opposed to an allegorical or metaphorical sense), to quote one of the genre's latest exponents. Thus Vallès's principle that "God cannot be deceived, nor can he deceive," is echoed by Daneau: "although it is conceded that he spoke simply, Moses should not be accused of having said anything or written on these things mendaciously, falsely, or ignorantly." Some common conclusions drawn from these principles include the existence of supercelestial waters (from Gen. 1:7) or the origins of underground springs from the oceans flowing back to their sources (from Eccles. 1:7). More generally, these philosophers emphasized the directly divine origins of natural phenomena. Aslakss $\emptyset$, for example, notes that although philosophers attribute the tides to the actions of the planets, it is clear from the Mosaic account that the tides existed before the planets; "therefore Scripture attributes them not only to the planets, but also to the admirable providence of God."41 Piety did not entail abandoning rational thought, however: these "Christian philosophers" mounted incisive attacks on received Aristotelian philosophy, pointing out its contradictions and absurdities, and could be receptive to the latest developments. Most notably, Aslakssøn, who had studied with Tycho Brahe in 1590-1593, favored Copernicanism in his De natura coeli triplicis (1597), but he was alone among Comenius's "Christian philosophers" in doing so. In its natural historical formulation, as a "physica specialis" focused on particulars (to use Aslakss $ø$ n's formulation), most of the conclusions of Christian philosophy steered clear of philosophically contentious areas. ${ }^{42}$

A bolder strategy of Christian physics involved trying to find in the Bible solutions to disputed questions in natural philosophy. Comenius, Casmann, and Alsted moved in that direction by treating Christian physics more systematically. In his treatment of "Physica Mosis, Jobi et Davidis" in a separate one-page section of his Encyclopedia (bk. 35, sect. 26), Alsted takes biblical passages as his point of departure (just as Vallès and Lemnius had) but focuses on the principles of natural philosophy that one finds there. He concludes from Genesis that there are three principles of natural things: heaven, light, and earth (he acknowledges a difference here with Daneau, who sees only two principles - the Bible is perhaps not the warrant against controversy that Comenius had hoped for after all). Prime matter is made fertile by the Holy Spirit, by the heavens, and by an internal principle; for the earth without the sky is like a woman without a man. His references turn to Paracelsus and Agrippa; from the Bible, he says briefly, one can easily deduce the "foundation of their more secret philosophy" - which is left unspecified. From Job we should learn oryctologia, the generation of fossils, and theriologia, the science of animals, such as the

\footnotetext{
${ }^{41}$ Samuel Pike, Philosophia sacra; or, The Principles of Natural Philosophy Extracted from Divine Revelation (London: Buckland, 1753), p. v. Vallès, De iis quae scripta (cit. n. 21), p. 6: "Certe [Deus] decipi non potest, neque decipere." Daneau, Physica christiana (cit. n. 23), pp. 23-24: "Sed ut simpliciter loquutus esse concedatur, non tamen mendaciter falso et ignoranter quicquam dixisse aut de iis rebus scripsisse convincetur Moses. Aliud est igitur fateri stylum Mosis nudum et simplicem esse, qualis oratio veritatem decet: aliud autem falsum et mendacem eum affirmare, quod nemo potest, nisi perfrictae conscientiae homo." Aslacus, Physica et ethica mosaica (cit. n. 20), p. 225: "An fluxu et refluxu maris ex sideribus tantum pendeat? Philosophi sic statuunt. At ex Mose liquet mare ipsum eiusque terminos, item fluxum et refluxum ante solis et reliquorum siderum productionem a Deo fuisse constituta. Et proinde scriptura non ad sidera tantum, sed ad mirabilem Dei providentiam haec refert. Iob. 3. Ierem. 5. 22."

${ }^{42}$ This point is also made in Armogathe, "Physica sacra de Comenius" (cit. n. 14), p. 10. On Aslakssøn's view of Copernicanism see Shackelford, "Rosicrucianism" (cit. n. 25), p. 189, citing Oscar Garstein, Cort Aslakssфn: Studier over dansk-norsk universitets- og lardomshistorie omkring år 1600 (Oslo: Lutherstiftelsen, 1953), pp. 191, 198.
} 
whale and the elephant. From David (i.e., Psalms) we learn brontologia, the physiology of thunder and lightning, which requires the greatest courage, as "Hermes says in the tabula smaragdina." This is the extent of Alsted's allusive treatment. Mosaic physics is presented as separate from and complementary to the much longer (and more Aristotelian-although still eclectic) treatment of physics in an earlier book of the Encyclopedia. Mosaic physics enables Alsted to give special authority to elements of Paracelsian and Hermetic philosophy that appealed to his wide-ranging search for truth but that he never fully managed to reconcile, as he had planned, with more mainstream Aristotelian physics. ${ }^{43}$

Even for those most adamant (like Casmann and Comenius) about the need to overthrow the slavish adherence to Aristotle in the name of free and Christian philosophy, the changes involved in practice are not very evident. The early historians of philosophy dismissed Mosaic philosophers precisely on these grounds. Morhof concluded that Daneau, Aslakssøn, Alsted, and other authors of Christian physics had followed no certain principles: they either simply commented on Genesis or reduced received Aristotelian physics to the Mosaic principles. J. F. Budde used the example of Casmann to illustrate his broader assessment of those listed by Comenius: in short, they did nothing but confirm scholastic philosophy from the Bible and were more opposed to Aristotle in words than in reality. Indeed, overthrowing Aristotle was easier boasted of than carried out. Furthermore, the Christian philosophers, in attacking a slavish adherence to Aristotle, did not mean to reject received philosophy entirely but to supplement and correct it where necessary according to biblical truth. Thus Daneau cites many philosophical authorities favorably and, for example, defines lightning and thunder in terms of Aristotelian exhalations before giving examples from the Bible showing their deeper, supernatural origins. ${ }^{44}$ After long, impassioned programmatic chapters, Casmann offers ten short chapters covering the disciplines: grammar, rhetoric, logic, arithmetic, geometry, optics, music, physics, metaphysics, and ethics and politics, following the lead of Alsted's Triumphus bibliorum. But the treatment is tantalizingly brief: in a four-page chapter on "Christian physics," the reader is sent off with the

\footnotetext{
43 "Physica Mosis, Jobi et Davidis," in Johann Heinrich Alsted, Encyclopedia (Herborn, 1630; facsimile ed., Stuttgart/Bad Cannstatt: Frommann-Holzboog, 1989-1990), Vol. 4, p. 2350. It is followed by a longer section entitled "Theosophia et philosophia Salomonis." Ibid., p. 2350: "Hinc [Gen. 2.7] enim facile potest deduci fundamentum secretioris philosophiae de terra Adamica apud Agrippam et de Limbo apud Paracelsum." In his detailed study of Alsted's thought, Howard Hotson finds that Alsted's treatment of physics follows a pattern common to his treatment of other disciplines, in which he calls for, but never carries out very far, a harmonization of competing positions. See Howard Hotson, "Johann Heinrich Alsted: Encyclopedism, Millenarianism, and the Second Reformation in Germany” (D.Phil. thesis, Oxford Univ., 1991), esp. pp. 137-144; and Hotson, Johann Heinrich Alsted: Between Renaissance, Reformation, and Universal Reform (Oxford: Oxford Univ. Press, 2000).

${ }^{44}$ Morhof, Polyhistor (cit. n. 6), p. 160: "Lamb Danaeus, Conr. Aslacus, Joh. Henr. Alstedius ... ac alii qui Physicam Christianam scripserunt, nulla certa principia sequuntur, sed vel Interpretes sunt priorum Capitum Genesos, vel Physicam Aristotelicam et vulgarem ad Mosaica illa reducunt." Buddeus, Introductio ad historiam philosophiae ebraeorum (cit. n. 10), pp. 258-259: "Ceterum fuerunt adhuc plurimi, qui christianam se sequi philosophiam professi sunt, quorum praecipuos ex Comenio supra nominavimus: ast tamen qui inter Ebraeae philosophiae propagatores praeter Comenium et Bayerum referri mereantur, non vidimus. Plerique enim eorum, qui Christianam philosophandi rationem sequi videri voluerunt, nihil tamen fecerunt aliud, quam ut doctrinam scholasticam, quam a teneris hauserunt unguiculis, ex Scriptura Sacra confirmarent et stabilirent. . . Hi ergo si Aristotelicam aut scholasticam reiecisse videntur philosophiam, verbis potius quam reipsa hoc fecerunt." Daneau, Physices christianae pars altera (cit. n. 23), chs. 28-29, as discussed in Max Engammare, "Controverses autour de la foudre et du tonnerre au soir de la Renaissance," Mélanges de l'Ecole Française de Rome: Italie et Méditerranée (forthcoming). I am grateful to the author for a copy of this paper. See also Christoph Strohm, Ethik im frühen Calvinismus: Humanistische Einflüsse, philosophische, juristische und theologische Argumentationen sowie mentalitätsgeschichtliche Aspekte am Beispiel des Calvin-Schülers Lambertus Danaeus (Berlin/ New York: De Gruyter, 1996), pp. 66-69.
} 
standard definitions and subdivisions (animate and inanimate, rational and irrational, etc.), the standard justifications of the discipline (its piety, utility, and agreeableness), two bibliographical references (Daneau and Lemnius), and references to passages in Job and Genesis. The message is that the reader should "go do it himself" through direct contact with the sacred texts and without much guidance from authorities, true to Protestant tradition. Budde concludes that Casmann should be praised for his call to subdue scholastic philosophy, although he did not carry it out with great success. ${ }^{45}$

Even Comenius, whom Morhof and Budde consider more consistent and successful than the other "Christian philosophers," reduces his natural philosophy reformed by divine light to a Ramist-style succession of short definitions and explanations, variously supported by biblical references and Paracelsian authors, that also include noticeable, and unacknowledged, similarities with Aristotelian conclusions (that spring waters form from vapors condensed in the caverns of the earth, for example) ${ }^{46}$ Certainly one can detect in Comenius and parts of Alsted a greater role for Paracelsian principles, which came with explicit Christian credentials and a clear anti-Aristotelian agenda. But none of these authors made a very sustained effort to rebuild on new foundations: "pious philosophy" functioned mostly as an inspiring platform from which to attack enemies among both philosophers and theologians. Furthermore, by its very agenda, pious philosophy perhaps inevitably involved a certain amount of philosophical silence-it was designed precisely to avoid the excessive philosophical niceties characteristic of scholastic Aristotelianism.

Acknowledging the limits of reason and the impossibility of a purely philosophical explanation was itself one of the tactics of pious philosophy. Thus Vallès proclaims in one sentence the glory of God and the weakness of the human mind (which requires the guidance of the Church, true to Catholic tradition); Daneau chastises heathen philosophy for its arrogance in failing to recognize the greatness of God. ${ }^{47}$ One can find elements of a similar strategy in Robert Boyle, who was also concerned that his philosophy serve piety and as a result emphasized the weakness and limits of human reason. Like the Christian philosophers I have considered here, Boyle also offered both a defense of religion against natural philosophers inclined toward excessive naturalism and atheism and a defense of natural philosophy against "timid Christians" who criticized philosophy as a threat to piety. But, in a crucial divergence from Comenius's "most Christian philosophers," Boyle followed Bacon in advocating a separation between philosophy and theology and repeated Bacon's warning against "unwisely mingling and confounding" the two. ${ }^{48}$ As a result,

\footnotetext{
${ }^{45}$ Casmann labels these disciplines "Christian" except for the four quadrivial ones; among them, optics has replaced astronomy. See Casmann, Philosophiae ... modesta assertio (cit. n. 20); for the chapter on "Christian physics" see pp. 152-155. Alsted, however, included an "arithmetica sacra" and a "geometria sacra," devoted to biblical uses of numbers and sizes. See Alsted, Triumphus bibliorum (cit. n. 11), pp. $105 \mathrm{ff} ., 109$ ff. Buddeus, Introductio ad historiam philosophiae ebraeorum, p. 260: "Idem porro Casmannus eam ubique tenet tractandi rationem, quae a vulgari haud discrepat. In eo tamen laudandus, quod pro viribus iugo scholasticae philosophiae collum subducere elaboraverit, licet non adeo magno cum successu."

${ }^{46}$ Comenius, Naturall Philosophie Reformed by Divine Light (cit. n. 14), par. 53, pp. 140-141.

${ }^{47}$ Vallès, De iis quae scripta (cit. n. 21), p. 7: "Volo tamen haec in Dei gloriam, potius quam mei nominis celebritatem, scripta, atque rei tantae difficultatem, et humanae mentis debilitatem agnoscens. Testor ante omnia, nihil me in hoc, aut ullo alio meorum operum asserere, nisi quatenus probetur a sancta Romana Ecclesia." Daneau, Physica christiana (cit. n. 23), pp. 28-29: "Christiani Physici qui de rebus creatis agunt, suae disputationis summam eo referunt ut verus ille Deus Optimus Maximus, qui earum omnium autor est, parens et conditor, agnoscatur, laudetur, celebretur, denique colatur ardentius et magis timeatur. At Aristotelici et profani Physici ita de rerum natura disputant, ut in ipsis rebus tanquam infimis gradibus et in certa quadam vi (quae post earum creationem spectatur et quam naturam appellant) toti inhaereant, altius autem non assurgant, neque ad Deum opificem his tanquam scalis conscendant."

${ }^{48}$ See Wojcik, Boyle and the Limits of Reason (cit. n. 2). On Boyle's criticism of "timid Christians" see
} 
Boyle shunned divine intervention in explaining natural phenomena; natural philosophy should restrict itself to secondary causes, although these might not always be known. On this point Thomas Lydiat, whom Comenius was probably overeager to add to his camp, also disagreed with the other "most Christian philosophers." In criticizing the attribution of the saltiness of the sea to the action of God (Lydiat is referring here specifically to Patrizi, but Daneau also held similar views), he complains: "When he [Patrizi] could not find a natural cause for the saltiness of the sea, he took refuge in a supernatural one, so as not to be left without any cause, and therefore he confused physiology with theology; which sciences nonetheless, like all others, in our judgment, it is good to conjoin, but not to confuse." Lydiat then recommends the reasons Aristotle gives for the saltiness of the sea in Meteorology 2.3. ${ }^{49}$ For Lydiat, "Christian philosophy" had its limits, and, for lack of a new answer of his own, he preferred Aristotle to silence or supernatural intervention.

\section{CONCLUSION}

Clearly "pious philosophy" did not form a unified "school," as Comenius tried to suggest. Its unity stemmed from an agenda and a set of references (to the Bible and to other Christian philosophers, most prominently Vallès and Daneau) designed to defend natural philosophy from the excesses of both philosophical naturalism and theological obscurantism. The multiplication of such attempts in the late Renaissance was a response to the religious and philosophical crises that threatened the ability to believe in the existence of, let alone find, that single, harmonious truth that would unite philosophy and theology. The "pious philosophers" contributed to the attacks on Aristotelianism that multiplied in the late Renaissance but were less successful in offering a fully formed alternative philosophy. In interpreting the physics of the Bible they borrowed from Paracelsian and atomist philosophies, and, despite their anti-Aristotelian principles, they often let Aristotelian notions stand. Although assessments of "Christian physics" were largely negative in the histories of philosophy starting with Bayle and Morhof in the late seventeenth century, the term and the agenda remained current in some circles into the eighteenth century.$^{50}$ Their strategy also found successors among those who tried to apply the new, Cartesian or Newtonian, cosmologies to the text of Genesis, including Thomas Burnet, among other Cartesians, or the Newtonian William Whiston, both of whom Brucker includes among the "Mosaici et

\footnotetext{
Hooykaas, Robert Boyle (cit. n. 2), p. 59. For Boyle's citation of Bacon, discussed ibid., p. 86, see Robert Boyle, The Usefulness of Natural Philosophy, in The Works of the Honourable Robert Boyle (cit. n. 34), Vol. 2, p. 58, quoting Bacon, The Advancement of Learning, bk. 1. The passage can be found in Francis Bacon, The Advancement of Learning, Book I, ed. William A. Armstrong (London: Athlone, 1975), p. 55.

${ }^{49}$ Lydiat, Praelectio astronomica (cit. n. 20), p. 173: "Ita ille cum salsedinis marinae causam naturalem invenire non posset, ne nullam afferret, ad supernaturalem confugit, itaque Physiologiam cum Theologia confudit; quas tamen scientias sicut et alias omnes, nostra quidem iudicio, coniungi non confundi bonum est. Neque enim transitum a genere ad genus in ulla scientia aut facultate vel in alijs laudamus vel quoad nos concedimus. Mare igitur salsum esse propter rei alicuius admistionem etsi ex eo satis clarum est, quod omnis sapor misti sit qua mistum; probat tamen Aristoteles compluribus rationibus tertio secundi meteororum." Cf. Daneau, Physica christiana (cit. n. 23), p. 54.

${ }^{50}$ See Cotton Mather, The Christian Philosopher (London, 1721), ed. Winton Solberg (Urbana/Chicago: Univ. Illinois Press, 1994); and Samuel Pike, Philosophia sacra (cit. n. 41). Ahrbeck sees other successors in August Pfeiffer, Pansophia e Genesi delineata (1685), and Johann Jakob Scheuchzer, whose Physica sacra (1731) is most notable for its lavish copper engravings. See Ahrbeck, "Bemerkungen über 'Mosaische Philosophen'" (cit. n. 10), p. 1050.
} 
Christiani." 51 Nonetheless, these attempts at literalist reconciliations between the Bible and natural philosophy generally yielded by the late seventeenth century to two dominant alternative strategies, the separationist and the natural theological.

For those who advocated a separation of the natural philosophical and the biblical spheres, the natural philosopher dealt exclusively with philosophy and might be left, in the long run, with little sense of a religious motivation or constraint. Alternatively, for those in the filiation of Boyle and the English natural theologians, natural philosophy was justified as a contribution to the understanding and worship of God. Natural philosophers contributed to a natural religion, which would be supplemented by revelation on issues concerning Christian salvation. These natural theologians were "Christian" in their appellation (and this conception of themselves could have an impact on their scientific practice, as in the case of Boyle, for example) but maintained, by contrast with Comenius's "most Christian philosophers," a boundary between philosophy and theology, which were to be "conjoined" but not "confused." Over the long term this natural theological approach generated a religion that seemed to rely so strongly on the argument from design that when the latter faltered (notably under the impact of Darwin) the whole edifice of religious belief threatened to come down with it.

In this way these two strategies-strict separation (often favored by Catholics) and natural theology (a Protestant specialty) - tended toward the same result: a conception of nature as rationalized and law-bound, evidence of divine creation and general providence, but that left no room for supernatural intervention, biblical authority, or limits on the purview of reason in natural philosophy. Instead, the authors considered here represented one of the last set of attempts at a delicate balancing act to reconcile natural philosophy with a "true piety" beholden to biblical authority. Neither proponents of free philosophy nor obscurantist biblicists, they defended philosophy against those who would eradicate it and they insisted on taking biblical statements about nature seriously. Amid the many innovative natural philosophies competing during the sixteenth and seventeenth centuries, most of which proclaimed themselves "pious" in some way, these "most pious" philosophers represented an alternative strategy that has been largely forgotten in the depiction of early modern natural philosophy as the conflict between the Aristotelian traditionalists and the moderns. To study the nature and potential appeal of their strategy is to understand better the dynamics of contemporary debates and self-presentations, as all early modern philosophers grappled with the ideal of a pious philosophy - an ideal that the Mosaic philosophers pursued more single-mindedly than most.

\footnotetext{
${ }^{51}$ Thomas Burnet, Telluris theoria sacra (1681); and William Whiston, A New Theory of the Earth (1696). See Brucker, Historia critica (cit. n. 7), Vol. 4, pp. 621 ff., 625. Other Cartesians who attempted a reconciliation with Genesis include Johannes Amerpoel, Cartesius Mosaizans (1669); and Christopher Wittich, Consensus veritatis in scriptura divina . . . cum veritate philosophica a Renato Cartesio detecta (1659). I am grateful to an anonymous referee for the latter reference.
} 